\title{
Water masses distribution in the Southern Ocean: improvement of an extended OMP (eOMP) analysis.
}

\author{
Paula C. Pardo ${ }^{a}$, Fiz F. Pérez ${ }^{\mathrm{a}}$, Antón Velo ${ }^{\mathrm{a}}$, Miguel Gilcoto ${ }^{\mathrm{a}}$

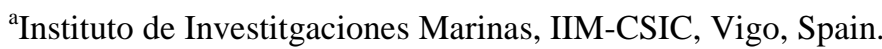 \\ *Corresponding author. Tel: +34 986231 930; fax: +34 986292762 \\ E-mail address: pconde@iim.csic.es.
}

\begin{abstract}
:
The Southern Ocean (SO) is a major part of the global ocean circulation. The formation and mixing of water masses in the SO cause changes in the northward flow of the Meridional Overturning Circulation and as a consequence, in the Earth's climate. There have been numerous studies of the SO but a full understanding is difficult to achieve due to the complexity of the processes of formation and mixing of the different water masses. This work aims to clarify some of these aspects through an extended Optimum Multiparametric analysis, using data downloaded from the GLODAP and CARINA databases. A total of 11 source water masses were selected accurately describe the physical and biochemical properties of the SO. Shelf surface waters were included in order to accommodate the complex shelf processes involved in the formation of Antarctic bottom waters. The methodology here developed takes into account the remineralisation of organic matter and as an improvement; the variability of data related to the processes of dissolution of $\mathrm{CaCO}_{3}$ and opal. The results from this analysis are accurate and reliable and led to very informative conclusions. Thus, a volumetric census is presented, which confirms Circumpolar Deep Water (CDW; $53 \pm 3 \%$ of the SO volume) as the most volumetrically important water mass in the SO; followed by Antarctic Bottom Water (AABW; $17 \pm 0.9 \%$ ) and North Atlantic Deep Water (NADW; $13 \pm 0.8 \%$ ). AABW properties are the result of the predefined combination of its three major types, i.e., 77\% Weddell Sea Bottom Water, 20\% Ross Sea Bottom Water and 3\% Adélie Bottom Water. CDW comprises 65\% AABW, 30\% NADW and 5\% Antarctic Intermediate Water, according to the relationship between their conservative properties (potential temperature and salinity). Therefore, the volume occupied by AABW and NADW in the SO rises to $51 \pm 2 \%$ and $28 \pm 0.8 \%$, respectively. The ratio between $\mathrm{AABW}$ and NADW is $1.79 \pm 0.03$, which is inside the expected range of $1-3$. Considering the Atlantic sector of the $\mathrm{SO}\left(70^{\circ} \mathrm{W}-80^{\circ} \mathrm{E}\right)$, which is the more relevant in terms of $\mathrm{AABW}$ production (AABW represents $60 \pm 0.2 \%$ of the volume of the sector), the estimated ventilation time is approximately 250 years, the same period as for the whole SO. This demonstrates the very important role of shelf processes in the quantity of AABW formed in the SO and its crucial role in terms of global climate.
\end{abstract}

Keywords: Southern Ocean; water masses; OMP; volumetric census; Multiparametric analysis.

\section{Introduction}


The Southern Ocean (SO) plays an important or even crucial role in the global climate system (Wüst, 1935; Deacon, 1937, 1984). The SO is a global ocean connector, acting as the crossroads of the global ocean circulation (Rintoul et al., 2001; Sloyan and Rintoul, 2001; Lumpking and Speer, 2007; Iudicone et al., 2008). The Antarctic shelf is the zone of formation of one of the most important water masses of the global ocean, i.e., Antarctic Bottom Water (AABW). AABW flows northwards, together with the intermediate and deep waters generated within the SO. They constitute the counter-clockwise part of the Meridional Overturning Circulation (MOC) and have important effects on the ventilation and heat transport at abyssal and intermediate depths of the world's oceans. The southward flux of the MOC is driven by deep waters coming from the North Atlantic; the North Atlantic Deep Water (NADW).

The unique geography of the SO extends from the Antarctic coast north to $45^{\circ} \mathrm{S}$ (Fig. 1). The strong Southern Hemisphere Westerly winds drive the Antarctic Circumpolar Current (ACC), which is a deep and vigorous current flowing eastward around the Antarctic continent. The ACC varies with longitude and is greatly influenced by bottom topography (Gille, 1994). Circumpolar Deep Water (CDW) is found within the ACC and it is considered the most voluminous water mass of the world oceans (Worthington, 1981). In winter, deep convection on the equator side of the ACC forms a vertically mixed layer known as Sub-Antarctic Mode Water (SAMW; McCartney, 1977). Antarctic Intermediate Water (AAIW) is located beneath the SAMW and both participate in ventilating the thermocline of the surroundings and of other oceanic regions as they spread northwards (Rintoul and Bullister, 1999; Talley, 2003).

The dense Antarctic Bottom Water (AABW) sinks to abyssal depths when forming around some areas of the Antarctic shelf (Jacobs et al., 1970, 1985; Orsi et al., 1999; Gordon et al., 2004). Actually, AABW refers to several varieties of bottom waters produced and exported around the Antarctic continental margins. The sources of AABW types (Fig. 1) are well-documented and are located in the Weddell Sea (Weddell Sea Bottom Water, WSBW), in the western Ross Sea (Ross Sea Bottom Water, RSBW) and along the Adélie coast of Wilkes Land (Adélie Bottom Water, ADLBW) (Orsi et al., 1999, 2002). AABW formation is rather complicated as it involves poorly understood shelf processes and mixing of different water masses (Gill, 1973; Foster and Carmack, 1976). The growth of sea ice within Antarctic coastal polynyas is an effect of the cold and intense offshore winds (Arrigo and Van Dijken, 2003), resulting in salt rejection and the increase of surface salinity. Dense waters sink, driving deep convection and bringing waters high in both nutrients and $\mathrm{CO}_{2}$ to the surface (Arrigo et al., 2008). Eventually, in all these places of the Antarctic shelf, CDW mixes with younger waters of local origin, producing recently ventilated waters known as Modified Circumpolar Deep Water (mCDW; Newsom et al., 1965; Withworth et al., 1998), which is injected into mid-depth layers and contributes to the formation of the different types of AABW. Sea-ice formation within the Antarctic shelf converts local upper waters, like the near-freezing Antarctic Surface Water (AASW) or the shoaling mCDW into Shelf Water (SW); the densest water mass found around Antarctica (Whitworth et al., 1998). Different types of SW are identifiable by their extreme temperatures and/or salinities, as in the case of High Salinity Shelf Water (HSSW; Orsi et al., 2002), which is recognisable by its core of salinity values around 34.8 (Table 1).

Despite much scientific effort and a huge amount of literature on water mass formation, circulation and exchange within the SO, the need for a full understanding is still required. One of the aims of this work is to provide an accurate estimation of the mixing and distribution of the most representative water masses of the SO, from the Antarctic continent north to $45^{\circ} \mathrm{S}$ (Fig. 1). A total of 11 water masses were selected which best characterise the specific features of the 
TS-diagram of the SO (Fig. 2, Table 2): CDW, SAMW (two branches will be considered), AAIW, NADW, ADLBW, RSBW, WSBW, AASW, HSSW. Also included is the Sub-Tropical Central Water (STCW), which is an artificial water mass added because the region of study extends northwards to $45^{\circ} \mathrm{S}$. Source data were downloaded from the global CARINA and GLODAP databases to estimate the contribution $\left(X_{i}\right)$ of each of these water masses. The values of $X_{i}$ were obtained using a non-negative least squares method, for an extended OMP (eOMP) analysis (Tomczak, 1981). The methodology presented here is improved in order to account for biogeochemical processes affecting non-conservative variables. Another goal of this study is to illustrate the usefulness of these results for estimating a volumetric census of the main water masses involved in the SO circulation. Finally, some estimates of the ventilation time for $\mathrm{AABW}$ are also given.

\section{Observations and Methods}

\subsection{Data}

A total of 82792 data with measurements of seven main properties (Potential Temperature [ $\theta$ ], Salinity [S], Oxygen $\left[\mathrm{O}_{2}\right]$, Nitrate $\left[\mathrm{NO}_{3}\right]$, Phosphate $\left[\mathrm{PO}_{4}\right]$, Silicate $\left[\mathrm{SiO}_{2}\right]$ and Total Alkalinity $\left[\mathrm{A}_{\mathrm{T}}\right]$ ) were downloaded from the GLODAP and CARINA databases, covering the area from the Antarctic continent north to $45^{\circ} \mathrm{S}$, (Fig. 1). During the 1990s, a compendium of data from the WOCE/JGOFS/OACES cruises was established in an oceanographic database thanks to the cooperative effort of different international entities within the Global Ocean Data Analysis Project (GLODAP, http://cdiac.ornl.gov/oceans/glodap/Glodap_home.html). All data were merged into a common format set and subjected to rigorous quality control procedures to eliminate any systematic data measurement bias (Key et al., 2004). The CARINA data synthesis project (http://store.pangaea.de/Projects/CARBOOCEAN/carina/index.htm, NDP 091) started in 1999 as an informal collaboration. From 2005 with funding under the EU IP CARBOOCEAN, the collection of data was extended to other regions of the world's oceans. High quality data from CLIVAR cruises were included, together with the WOCE results, to serve as "master cruises" for the data calibration (2nd QC) phase of the synthesis. The result was an internally consistent merged data set of open ocean subsurface measurements that was subjected to extensive quality control and adjustments when necessary. Many of the procedures used during CARINA were adopted from GLODAP. However, the number of cruises included in CARINA, combined with the additional manpower and funding available from CARBOOCEAN, allowed improvements. Most of the CARINA SO data originate from the post-GLODAP era, i.e., from 2000 or later. Regional specific quality control is described in three papers; for the Pacific sector by Sabine et al. (2009), the Indian sector by Lo Monaco et al. (2009) and the Atlantic sector by Hoppema et al. (2009).

\subsection{Thermohaline context: Source Water Masses}

The SO connects to the global climate system via important global scale mechanisms, such as the MOC, which is the most important mechanism for ventilating the global ocean. The MOC comprises two circulation cells: the clockwise circulation cell driven by NADW going southward from the arctic and the counter-clockwise cell mainly transporting water from the Antarctic continent to northern latitudes, which is driven by AABW. Both cells converge within 
the SO. Therefore, the TS-diagram of this ocean should result from the mixing of the two major water masses driving the MOC (AABW and NADW) and a variety of other important water masses originally formed within the SO. The 11 Source Water Masses (SWMs) selected here, encompass the TS-diagram of the SO (Fig. 2, Table 1).

Upper and lower components of NADW form in the northern North Atlantic. Winter cooling in the Labrador Sea (North Atlantic region, north of $50^{\circ} \mathrm{N}$ ) and ocean convection processes (Lazier, 1973; Talley and McCartney, 1982) help the formation of the densest and coldest water of the North Atlantic region, the Classical Labrador Seawater (cLSW). On the other hand, Iceland-Scotland Overflow Water (ISOW) and Denmark Strait Overflow Water (DSOW) enter the world's deep ocean through gaps in the Greenland-Iceland-Scotland Ridge. ISOW enters the eastern basin of the North Atlantic region and continues to the western basin where it meets DSOW (Smethie, 1993; Doney and Bullister, 1992). cLSW and the two overflows (ISOW and DSOW) mainly compound NADW, which flows southward within the North Atlantic deep western boundary current, until it reaches the densest portion of the CDW associated with the ACC (Orsi et al., 1999). In the South Atlantic, Brea et al. (2004) defined the thermohaline and chemical characteristics of the upper-middle and lower part of NADW based on the classical definition and circulation scheme of Wüst (1935). This work defined NADW (Table 1) as a unique point in the TS-diagram with thermohaline and chemical characteristics halfway between the NADW segments defined by Brea et al. (2004).

Between the Subantarctic Front (SAF) at the north and the Polar Front (PF), the strong and deep ACC flows eastward around the Antarctic Continent (Orsi et al., 1995; Belkin and Gordon, 1996). The ACC presents a thick layer where the isopycnals shoal to the Antarctic continent, favouring the exchange of water and properties between the SO and the northern deep basins (Orsi et al., 2002). CDW occupies this thick meridionally tilted layer and is defined as a composite of deep waters flowing from the Atlantic, Pacific and Indian basins that eventually mix with the ventilated waters surrounding the Antarctic continent (Whitworth III et al., 1998; Rintoul et al., 2001). Even though CDW is per se a water mass formed by the mixing of several others, it is considered as an SWM because of its relevance in the processes of formation of ABBW. In order to obtain the properties of CDW (Table 1), averaged values of the properties were calculated for those data of the TS-diagram located between the SAF and the PF and in the upward confluence zone of the three types of bottom water (Fig. 2b). The properties obtained for CDW are close to those of the mCDW defined by Newsom et al. (1965).

North of the SAF, deep winter convection forms SAMW, a vertically well-mixed layer with low potential vorticity and high oxygen content. SAMW spreads northwards as far as the subtropical gyres, renewing the water of the lower thermocline (McCartney, 1977, 1982; Talley 2003) and participates in the shallow overturning circulation linking the Pacific and Indian oceans (Ribbe, 1999; Sloyan and Rintoul, 2001). The properties of SAMW were taken as a line connecting SAMW1 and SAMW2 (Table 1) in order to best enclose the TS-diagram and differentiate the two varieties of SAMW (Rintoul and Bullister, 1999; Sloyan and Rintoul, 2001), i.e., the cool branch from the southeast Pacific (SAMW2) and the warm branch from the Indian Ocean (SAMW1).

The coldest varieties of SAMW in the Pacific and Atlantic oceans supply AAIW of those basins (McCartney 1982; Talley, 1996, 2003). AAIW is formed from upwelled CDW near the SAF and it is identified by a salinity minimum beneath SAMW (McNeil et al., 2001). AAIW, together with SAMW, are relevant in ventilating the Sub-Antarctic Zone and other regions of 
the ocean (Rintoul and Bullister, 1999). The properties of AAIW (Table 1) were taken in between the values of AAIW1 (coldest type of AAIW identified by Piola and Gordon (1989)) and AAIW2 from Brea et al. (2004).

Deep cores of high concentrations of CFC-11 can be found at several places around Antarctica, identifying zones of formation of AABW (Jacobs et al., 1970, 1985; Mantisi et al., 1991; Archambeau et al., 1998; Meredith et al., 2001; Orsi et al., 2002; Gordon et al., 2004). Three different zones over the Antarctic continental slope are well-documented source zones of the three main types of AABW: the Weddell Sea $\left(25-30^{\circ} \mathrm{E}\right)$, the Ross Sea $\left(168-173^{\circ} \mathrm{W}\right)$ and the Adélie coast in Wilkes Land $\left(135-155^{\circ} \mathrm{E}\right)$ (Orsi et al., 1999, 2002). The Weddell Sea is the zone of formation of Weddell Sea Bottom Water (WSBW), the coldest and freshest variant of AABW (Table 1) that upwells in the Weddell-Enderby basin and mixes into the more widespread AABW (Gordon and Huber, 1990; Orsi et al., 2001). ADLBW forms off the Adélie Coast (Gordon and Tchernia, 1972; Rintoul, 1998) and George V Coast (Carmack and Killworth, 1978; Jacobs 1989; Foster, 1995), approximately between $140-147^{\circ} \mathrm{E}$ and its properties lie between those of WSBW and RSBW (Table 1). The different outflows of RSBW from the Ross Sea are located between $168^{\circ} \mathrm{W}$ (Locarnini, 1994; Budillon et al., 2002) and near $173^{\circ} \mathrm{E}, 177^{\circ} \mathrm{E}$ and $175^{\circ} \mathrm{W}$ (Jacobs et al., 1970, 1985) and ventilate both the Pacific and Indian basins (Orsi et al., 1999). RSBW is the warmest and saltiest of the three types of bottom waters (Table 1). The formation of WSBW, RSBW and ADLBW is complicated, involving shelf processes and mixing of different water masses, such as mCDW and local shelf waters (Foster and Carmack, 1976; Weiss et al., 1979; Orsi et al., 2002). Thermohaline and chemical properties of ADLBW, WSBW and RSBW (Table 1) were obtained as boundary values close to the end of each of the three branches observed for bottom layers in the TS-diagram (Fig. 2b) and corroborated by values given by other authors (Orsi et al., 1999, 2002; Tomczak and Liefrink, 2005).

The MOC brings CDW to the Antarctic shelf where it is upwelled and transformed into upper waters (Gordon and Huber, 1984, 1990) commonly known as mCDW (Newsom et al., 1965). mCDW is produced by diapycnal mixing with the near-freezing local surface waters, such as AASW and HSSW, differentiated by their low and high salinity values, respectively (Whitworth and Orsi, 2006; Padman et al., 2008). Sea-ice formation converts local surface water and/or mCDW into SW, which is modified constantly by vertical mixing, producing dense transitional waters that flow to the bottom layers forming the different types of AABW (Gill, 1973; Foster and Carmack, 1976; Fahrbach et al., 1995; Gordon et al., 2001). Smith et al. (1984) considered AASW to be the result of the combination of Summer Surface Water, a highly variable water layer found above a seasonal halocline with low salinity values and Antarctic Winter Water. Although the processes of local surface water formation are not well known, HSSW is more likely to be produced within coastal polynyas, where the ice-formation creates salty surface waters (Orsi et al., 2002). The properties of AASW and HSSW were obtained after averaging points near the shelf with low and high extreme salinity values (lower points of the TS-diagram) and comparing the values obtained with those given by different authors (Orsi et al., 2002; Tomczak and Liefrink, 2005; Orsi and Wiederwohl, 2009; Williams et al., 2010).

Finally, because the region of study extends as far as $45^{\circ} \mathrm{S}$, the influence of subtropical waters should be taken into account in order to enclose the upper features in the TS-diagram (Fig. 2), i.e., in order to define the upper limit of the TS-diagram. Therefore, Sub-Tropical Central Water (STCW) represents the subtropical waters from the three major oceans surrounding the SO. Their properties were assigned as the upper limit of the TS-diagram, very close to those of 
upper Western South Pacific Central Water in Tomczak and Liefrink (2005). Indeed, any point in the TS-diagram between STCW and SAMW1 can be defined as a Sub-Tropical Central Water.

\subsection{OMP analysis}

Optimum Multiparametric (OMP) analyses (Tomczak, 1981; Thompson and Edwards, 1981; Mackas et al., 1987; Tomczak and Large, 1989) are mathematical approximations based on real data, which can be used to study the mixing processes between water masses in a certain region, whether the mixing processes are diapycnal or isopycnal. They have been widely used in the scientific community, subject to some improvements and serving as a basis for other new methodologies (You and Tomczak, 2003; You, 1997; Castro et al., 1998; Coatanoan et al., 1999; Lo Mónaco et al., 2005; Johnson, 2008). All varieties of OMP analysis consider the physical and/or chemical properties measured at each point, to be the result of the mixing of a certain number of water masses present in the region, which are called Source Water Masses (SWM) and whose physical-chemical characteristics are well-known. The contribution of each SWM $\left(X_{i}\right)$ to these mixing processes is the final objective of the analyses. The OMP analyses are based on the following assumptions: a) the mixing processes between SWMs are linear; b) the observed properties are conservative and c) the SWMs properties are accurately known (though associated with a standard deviation). Additionally, the OMP analyses are constrained to fulfill two rules: a) the mass balance equation has to be satisfied at any point and b) the mixing contributions of the different SWMs have always to be positive. The contribution of each SWM $\left(X_{i}\right)$ is estimated for each measured point using a non-negative least squares method. The obtained $X_{i}$ values are in the range $0-1$ and refer to the amount of a certain SWM "i" that is implicated in the mixing processes.

These very intuitive approaches are to some extent limited by the fact that, in the marine environment, except for $\mathrm{S}$ and $\theta$, most of the observed properties are not strictly conservative, because they are involved in reactive processes associated with the major biogeochemical cycles. Different authors have used a variety of approaches to solve this. In certain cases, biogeochemical processes can be considered negligible, e.g., when the region of study is not characterised by strong biogeochemical activity and it is small enough for the SWMs to be defined locally (Mackas et al, 1987; Tomczak, 1981). In a more conceptually correct manner, another way to maintain the assumption of conservativeness (b) consists of considering some conservative parameters associated with non-conservative properties (e.g., $\mathrm{NO}=\mathrm{r}_{\mathrm{O} / \mathrm{N}} \mathrm{NO}_{3}+\mathrm{O}_{2}$, $\mathrm{PO}=\mathrm{r}_{\mathrm{O} / \mathrm{P} O} \mathrm{NO}_{3}+\mathrm{O}_{2}$ (Broecker, 1974), $\mathrm{SiO}=\mathrm{r}_{\mathrm{O} / \mathrm{Si}} \mathrm{H}_{4} \mathrm{SiO}_{4}+\mathrm{O}_{2}$ (Castro et al., 1998; Johnson, 2008)). Therefore, one further assumption must be added to the previous ones: d) nonconservative properties are used and formed following a predefined stoichiometric coefficient. In this work, this type of OMP analysis was used in the first step of the methodology (see subsection 2.4). This included $\mathrm{NO}$ and $\mathrm{PO}, \theta, \mathrm{S}$ and $\mathrm{SiO}_{2}$ as conservative variables and was called Classical OMP (cOMP) analysis (Tomczak, 1981). NO and PO were calculated considering the stoichiometric coefficients $r_{\mathrm{O} / \mathrm{N}}=9.3$ and $\mathrm{r}_{\mathrm{O} / \mathrm{P}}=135$ (Broecker, 1974).

There is another strategy consisting of directly including non-conservative variables in the equations, by adding a biogeochemical term ( $\Delta O$ in this work) related to the non-conservative variable, through a predefined stoichiometric coefficient $\left(\mathrm{r}_{\mathrm{O} / \mathrm{N}}=9.3\right.$ and $\mathrm{r}_{\mathrm{O} / \mathrm{P}}=135$ for $\mathrm{NO}_{3}$ and $\mathrm{PO}_{4}$, respectively). This procedure is called extended OMP (eOMP) analysis. In this work, one 
further step is added in the use of the eOMP analysis, by the inclusion of two more nonconservative variables, $\mathrm{A}_{\mathrm{T}}$ and $\mathrm{SiO}_{2} . \mathrm{SiO}_{2}$ can be used as a conservative variable with respect to the processes of remineralisation of organic matter. However, this is only true when other biogeochemical processes are not considered, such as the dissolution of opal, base for some shell structures. On the other hand, $A_{T}$ is subject to variations due to the processes of remineralisation of organic matter $\left(\mathrm{r}_{\mathrm{O} / \mathrm{AT}}=-9.3\right)$ but, in a similar way to $\mathrm{SiO}_{2}$, it is also affected by the process of dissolution of $\mathrm{CaCO}_{3}$, which is also linked with shell structures of some seawater organisms. Evidence for the relation between $\mathrm{A}_{\mathrm{T}}$ and $\mathrm{SiO}_{2}$ was given by Rios et al. (1995) and some studies about identification of natural bomb radiocarbon $\left({ }^{14} \mathrm{C}\right)$ also show the positive correlation between the decay of ${ }^{14} \mathrm{C}$ and the dissolution of $\mathrm{CaCO}_{3}$ and opal (Broecker et al., 1995; Rubin, 2002). From all these studies, the coincident long-term accumulation of dissolved $\mathrm{CaCO}_{3}$ and opal can be assumed and a stoichiometric coefficient can be created relating both variables, i.e., $R_{\mathrm{Si} / \mathrm{Ca}}=1 / 0.48$ and $\mathrm{R}_{\mathrm{AT} / \mathrm{Ca}}=2$ (Rubin, 2002). Thus, one further unknown has to be considered, $\triangle C a$, and the system of equations stays in its final version as follows:

$$
\left\{\begin{array}{c}
\theta=\sum_{i=1}^{11} X_{i} * \theta_{i}^{0}+\varepsilon_{\theta} \\
S=\sum_{i=1}^{11} X_{i} * S_{i}^{0}+\varepsilon_{S} \\
O_{2}=\sum_{i=1}^{11} X_{i} * O_{2 i}^{0}-\Delta O+\varepsilon_{O_{2}} \\
N O_{3}=\sum_{i=1}^{11} X_{i} * N O_{3 i}^{0}+r_{O / N} \Delta O+\varepsilon_{N O_{3}} \\
P O_{4}=\sum_{i=1}^{11} X_{i} * P O_{4 i}^{0}+r_{O / P} \Delta O+\varepsilon_{P O_{4}} \\
A_{T}=\sum_{i=1}^{11} X_{i} * A_{T i}^{0}+r_{O / A_{T}} \Delta O+R_{A_{T} / C a} \Delta C a+\varepsilon_{A_{T}} \\
S_{i}=\sum_{i=1}^{11} X_{i} * S_{2} O_{2 i}^{0}+R_{S i / C a} \Delta C a+\varepsilon_{S_{i O}} \\
1=\sum_{i=1}^{11} X_{i}+\varepsilon_{\text {mass }}
\end{array}\right.
$$

where $\varepsilon$ are the relative errors for each one of the variables

\subsection{Mixing figures and methodology of the analysis}

The processes of mixing and interaction between SWMs (Table 1, Figure 2) in the SO are not well known. Nevertheless, they are to some extent intuitive and many of them assured in basis in the available literature. Thus, from the TS-diagram (Fig. 2) and taking into account the vertical distribution of the SWMs, as well as the thermohaline circulation within the SO, different groups of SWMs involved in a mixing process can be identified. Each of these groups is called a mixing figure (Figure 2c) and all of them are defined so that each mixing figure has almost one SWM in common with the neighbouring mixing figure. This procedure allows the eOMP analysis to be performed separately for each figure without losing continuity or strength. A total of 6 mixing figures were designed in this work (Fig. 2c). 
Once the main SWMs (Fig. 2, Table 1) and the mixing figures are established (Fig. 2c), the methodology for obtaining the SWMs contributions to the mixing through the OMP analysis $\left(X_{i}\right)$, was as follows. First, a cOMP (with $\theta, \mathrm{S}, \mathrm{SiO}_{2}, \mathrm{NO}$ and $\mathrm{PO}$ ) was applied to each dataset (or point) in each mixing figure, in order to obtain the mixing figure that best explains the observed properties, i.e., the mixing figure with the lowest total residual. Then, an eOMP was applied within the selected mixing figure and the contributions of the SWMs were obtained $\left(X_{i}\right)$, together with the parameters relative to the remineralisation of the organic matter $(\Delta O)$ and the dissolution of $\mathrm{CaCO}_{3}$ and opal $(\triangle C a)$.

Importantly, not all the variables are considered equally in the system of equations, i.e., each equation of the system has different weights (Table 1). The assignment of weights is, as a first step, directly related to the accuracy of the measured property. Several tests were done in order to assess the effect that changes in the different values of the weights have over the results. The weights were also adjusted so that the ratios between the SEE (Standard Error of the Estimate) and the analytical error $(\varepsilon)$ were almost the same for all the SWMs' properties (Table 1). The weights of $\theta$ and $S$ are higher than those of the other properties because both properties have the lowest analytical errors. $\theta$ has the highest weight because it acts as a better SWM tracer than S in the SO (warm waters in the subsurface layers are differentiated from cold bottom waters and warmer inner zones of the $\mathrm{SO}$ from frozen shelf waters) (Fig.2). $\mathrm{SiO}_{2}$ and $\mathrm{A}_{\mathrm{T}}$ have low weights because of low accuracy; $\mathrm{SiO}_{2}$ has the lowest weight of all because of the high variability of its accuracy.

In order to reduce the total error of the analysis, an iteration process was done forSiO $\mathrm{S}_{2}$ and $\mathrm{A}_{\mathrm{T}}$. Both these variables have the lowest accuracies, i.e., the ones that are going to accumulate more analytical error. During the iterations, new values of these properties are found for each SWM from $X_{i}$ and the data. These new estimated values (of $\mathrm{SiO}_{2}$ and $\mathrm{A}_{\mathrm{T}}$ ) are assigned to the $\mathrm{SWMs}$ as good ones and the methodology is re-run. The residuals of the variables, the total error of the analysis and the stoichiometric ratios are checked at the end of each iteration step and the variables changed accordingly. The process finishes when an asymptote is found in the value of the total residual of the analysis. The robustness and accuracy of the eOMP analysis was also tested through a perturbation analysis of uncertainties. The values of each of the SWMs properties were randomly modified under the assumption of them following a normal distribution. Each property value was considered as the mean value of the normal distribution and the standard deviation was fixed for some of the properties $\left(\theta, S\right.$, and $\left.A_{T}\right)$ at the same value of their accuracies and for the rest as a percentage of their values in each SWM (Table 1). 100 perturbations were run and the averaged results are shown in figures 3-6. The errors associated with the results are discussed in the Appendix section. The errors of the residuals are shown in Figure 8 and the uncertainties of $X_{i}, \Delta O, \Delta C a$ are shown in Figure 9 (see Appendix section).

\section{Results and discussion}

\subsection{Contributions of the main SWMs}

Four sections are shown to describe the spatial distribution of the contributions $\left(X_{i}\right)$ of the main intermediate to bottom SWMs of the SO (Figs 3, 4, 5, 6). One section (AA) surrounds the Antarctic continent (Fig. 3) and three meridional sections (A, P, I) start from the Antarctic continent and enter the Atlantic, Pacific and Indian sectors (Figs 4, 5 and 6). 
In section AA (Fig. 3) the path of CDW (Fig. 3b) around the Antarctic continent can be seen together with the variability of its position in the water column by the effects of changes in the bathymetry. The overall spreading of AAIW in intermediate waters and NADW in deep waters (Fig. 3a) are also evidence of the integrity of the results. Importantly, the maxima $(\approx 1) X_{W S B W}$ and $X_{R S B W}$ (Fig. 3c) are found in their respective zones of formation, i.e., the Weddell Sea and the Ross Sea. Small $X_{A D L B W}$ values (not shown) were found in eastern zones of the Indian sector near the Australian continent (between $90-170^{\circ} \mathrm{E}$ ) but this location is almost overlapped by the distribution of $X_{R S B W}$ (Fig. 3c). Gaps in the distribution of $X_{A A I W}$ and $X_{N A D W}$ (Fig. 3a) are probably due to the lack of stations in some zones of the section (Fig. 1).

Section A (Fig. 4) goes from the Antarctic shelf north to $45^{\circ} \mathrm{S}$ and is located in the western zone of the Atlantic sector (between $10-40^{\circ} \mathrm{W}$ ). The entrance of NADW and AAIW (Fig. $4 \mathrm{~b}, \mathrm{c}$ ) towards the Antarctic shelf can be seen, as well as the shoaling of CDW from $60^{\circ} \mathrm{S}$ to the vicinity of the Antarctic shelf (Fig. 4a). This is in accordance with the mechanism of formation of bottom waters described by different authors (Foster and Carmack, 1976; Weiss et al., 1979; Orsi et al., 2002). The presence of surface waters (HSSW and AASW, Fig. 4b) is not only visible in surface layers but also at $2000 \mathrm{~m}$ depth in the shelf-break and in the central deep layers of the section (between $60-55^{\circ}$ S). The presence of HSSW and AASW in the central deep layers could be an artefact of the eOMP but also it could be influenced by the shoaling bathymetry associated with the Drake Passage. Recent studies suggest that strong mesoscale activity near this zone could result in the deepening of surface-subsurface waters (Naveira et al., 2011). The important amount of WSBW found (Fig. 4c), together with the fact that no contributions of RSBW and ADLBW were detected (not shown), is strong evidence of the reliability of the analysis, as this section is located in front of the Weddell Sea where WSBW is formed. The distributions of $\triangle O$ and $\triangle C a$ (Fig. $4 \mathrm{~d}$, uncertainties are commented in the Appendix section and shown in Figure $9 \mathrm{c}$ ) show the maxima values of $X_{N A D W}$ and $X_{A A I W}$, at intermediatedeep layers. These results indicate that both terms could be considered as tracers for the arrival of "aged water masses", where biogeochemical processes have been acting for long time and high values of $\triangle O$ and $\triangle C a$ should be expected. Therefore, the renewed ventilated waters of the bottom can also be traced as minima values in both terms. $\Delta O$ presents low or even zero values in the bottom layers of the Weddell Sea area (between $70-60^{\circ} \mathrm{S}$, Fig. $4 \mathrm{~d}$ ) but this is not so for $\triangle C a$. The relatively high values of $\triangle C a$ in the bottom either is an artefact of the eOMP or could have an explanation in the effects of the high biological activity that can be found in the sediments (Hoppema et al., 1998).

The meridional section $\mathrm{P}$ (Fig. 5) is located in the Pacific sector, at $90^{\circ} \mathrm{W}$, near the Drake Passage. It follows an almost straight line from $70^{\circ} \mathrm{S}$ north to $45^{\circ} \mathrm{S}$. The relevant presence of SAMW (Fig. 5a) found in the northern zones of the region (between $60-45^{\circ} \mathrm{S}$ ) is probably related to its role in supplying AAIW (Fig. 5a) to the Pacific basin (McCartney, 1977, 1982; Talley 1996). Indeed, this is the area of formation of the cooler and fresher variety of SAMW described by some authors (Rintoul and Bullister, 1999; Sloyan and Rintoul, 2001). $X_{A A I W}$ and $X_{N A D W}$ (Fig. 5a, c) are also of considerable importance as well as $X_{C D W}$ (Fig. 5b). The shoaling of CDW as it approaches the coast is accompanied by the approach, shoaling and decline of NADW and AAIW (Fig. 5c, a). As expected, $\triangle O$ and $\triangle C a$ present the highest values in between the layers occupied by NADW and AAIW. Waters coming from intermediate and deep layers have been fed from the surroundings whilst travelling eastwards and have also incorporated inputs coming from the Pacific Deep Water (Talley, 2007; Kawabe and Fujio 2010) favouring 
biochemical processes to occur. Bottom waters present low values of $\Delta O$ and relative high values of $\triangle C a$.

Section I (Fig. 6) is located between $170-180^{\circ} \mathrm{E}$, in the vicinity of the western Ross Sea and goes from the Antarctic shelf in an almost straight line north to near $50^{\circ} \mathrm{S}$. $X_{A D L B W}$ (Fig. 6c) achieves relevant values in this zone close to its area of formation. As the shelf area is occupied by RSBW, ADLBW can only be distinguished away from the continent (Fig. 6b). This result could be an artefact of the analysis and a direct consequence of defining ADLBW with characteristics in between RSBW and WSBW. However,, it correspond to the circulation pattern within the Ross Sea gyre, described by Orsi et al. (1999), where part of the flow of RSBW spreads westward near the coast displacing ADLBW from its formation region to the outer bottom layers. In these eastern zones of the Indian sector, the signal of the WSBW (not shown) is almost completely lost. $X_{A A I W}$ (Fig. 6c) also shows relatively important values. AAIW deepens from the subsurface layers down to a depth of $2000 \mathrm{~m}$ in the northern part of the section, near South Australia. As shown in the previous sections, the presence of SAMW (not shown) and the shoaling of AAIW (Fig. 6c), NADW (Fig. 6b) and CDW (Fig. 6a) near the Antarctic shelf can also be seen. It is worth mentioning, though not shown in the figure, the distribution of $X_{H S S W}$ and $X_{A A S W}$, which can be found in the Antarctic shelf break to a depth of more than $3000 \mathrm{~m}$ corroborating its implication in the formation of bottom waters. $\triangle O$ and $\triangle C a$ show similar patterns to that of the other two sections, with high values located approximately between the maxima of $X_{N A D W}$ and $X_{A A I W}$. Near-zero values of $\triangle O$ and $\triangle C a$ are obtained in the area where the maximum of $X_{R S B W}$ appears indicating recently ventilated waters. Again, $\triangle C a$ shows relatively high values in the bottom layers off the shelf, where relevant values (but not maxima) of $X_{A D L B W}$ are also found.

\subsection{Volumetric Census}

Once the contributions $\left(X_{i}\right)$ of each SWM are obtained for each point, a volumetric census can also be estimated for all the SWMs (Table 2). First, a Water Mass Property (WMP) interpolation method (Velo et al., 2010) was applied in order to obtain values of $X_{i}$ in the WOA domain ( $1^{\circ}$ lat $\cdot 1^{\circ}$ lon, Fig. 7). This type of $3 \mathrm{D}$ interpolation takes into account the values of $\theta, S$, NO and PO measured at each point. Then, taking into account the volume of each box of the domain and the values of $X_{i}$, the volume occupied by each one of the SWMs can be estimated. Additionally, the thickness of each SWM in each of the cells of the domain was calculated and shown in Figure 7 (in $10^{3} \mathrm{~m}$ ).

NADW, CDW, AAIW and WSBW occupy the major volume within the SO (Table 2) and are the thickest (Fig. 7a, b, c, f) SWMs of the SO, except for NADW (Fig. 7a), which presents lower thickness than RSBW (Fig. 7e). As established by Worthington et al. (1981), CDW is the most voluminous water mass in the SO, representing $53 \pm 3 \%$ of the total volume $\left(23.8 \times 10^{16}\right.$ $\mathrm{m}^{3}$, Table 2) and it is also the thickest SWM, with a maximum thickness of $4.1 \cdot 10^{3} \mathrm{~m}$ near $180^{\circ} \mathrm{W}$. NADW and WSBW account for $13 \pm 0.8 \%$ and $13 \pm 1 \%$ of the total volume, respectively but the differences in their distributions can be established considering their thicknesses. WSBW (Fig. 7f) spreads mostly in the Atlantic sector and in zones near the Antarctic shelf of the Indian Sector, achieving a maximum thickness of $3.5 \cdot 10^{3} \mathrm{~m}$ west of the Weddell Sea. NADW (Fig. 7a) spreads all around the outer SO, presenting the maxima values of thickness $\left(1-1.2 \times 10^{3} \mathrm{~m}\right)$ mostly in the Atlantic sector, between $45-50^{\circ} \mathrm{S}$. AAIW occupies 10 
$\pm 0.5 \%$ of the SO volume and the maxima thicknesses $\left(>0.8 \times 10^{3} \mathrm{~m}\right)$ are obtained in zones of the eastern Pacific sector and of the western Atlantic sector (Fig. 7c). RSBW and ADLBW show lesser volumes and thicknesses than WSBW, accounting for $3 \pm 0.4 \%$ and $0.5 \pm 0.1 \%$ of the total SO volume and achieving a maximum of $1.6 \times 10^{3} \mathrm{~m}$ (Fig. $7 \mathrm{e}$ ) and $0.3 \times 10^{3} \mathrm{~m}$ (Fig. 7f) of thickness, respectively. Subsurface waters (STCW and the two branches of SAMW) account for $6 \pm 0.4 \%$ of the total volume but the volume occupied by STCW is almost negligible. Summed together, the subsurface waters account for a maximum of $1.2 \times 10^{3} \mathrm{~m}$ of thickness (not shown). Finally, Antarctic surface and shelf waters (HSSW and AASW) represent $1.5 \pm 0.07 \%$ of the total volume of the SO and achieve the maximum thickness $\left(1.1 \times 10^{3} \mathrm{~m}\right)$ in an area in front of the Weddell Sea coast (Fig. 7e). The relatively low volumes obtained for STCW, ADLBW, HSSW and AASW have to be understood with consideration of the distribution of data in the $\mathrm{SO}$, as well as the definition of these water masses and the number and distribution of data in each of the mixing figures. ADLBW has intermediate properties, between those of WSBW and RSBW and the three of them are included in the same mixing figure (mixing figure 5 , Fig. 2b, c). This can result in a higher percentage of contribution being given to WSBW and RSBW, as they are located at two of the extremes of mixing figure 5 and therefore they are more defining for mixing figure 5 than is ADLBW. This also causes the uncertainties of $X_{A D L B W}$ to be higher (in points of relatively high $X_{A D L B W}$ ) than for the other types of AABW. In the case of HSSW, AASW and STCW, their contributions could be underestimated because shelf and subtropical waters are poorly represented in the databases used (Fig. 1, Fig. 2).

As $\mathrm{AABW}$ is more available in the literature (in quantitative terms) than the three types of bottom waters, the volumes of WSBW, RSBW and ADLBW were summed to obtain that of AABW in order to compare results with previous works. The total volume of AABW in the SO is $3.9 \pm 0.2 \times 10^{16} \mathrm{~m}^{3}$, i.e., $17 \pm 0.9 \%$ of the $\mathrm{SO}$ volume (Table2) and the maximum thickness correspond to that of WSBW $\left(3.5 \times 10^{3} \mathrm{~m}\right.$, Fig. $\left.7 \mathrm{~d}\right)$. It is composed of $76 \%$ WSBW, $20 \%$ RSBW and 3\% ADLBW (Table 2). Taking into account this composition ratio, the properties of AABW are easily obtained (Table 1). Johnson (2008), through a least square analysis, also based on OMP analysis, estimated the volumes of the major SWMs implicated in the MOC to be $36 \% \mathrm{AABW}$ and $21 \% \mathrm{NADW}$, without considering CDW in the analysis. However, also in a global ocean study, Broecker et al. (1985) estimated the composition of common water ( CDW) to consist of $45 \%$ AABW (Southern component or $\sim$ WSBW), 25\% NADW and 30\% AAIW (coming from the Pacific and Indian oceans). This author considered $\mathrm{NO}$ and $\mathrm{SiO}_{2}$ as the conservative reference variables in order to obtain the composition of the common water. An estimation of the composition of the CDW was done based on the ratios between the values of $\theta$ and $\mathrm{S}$ (conservative properties in the improved eOMP analysis) of CDW and those of AABW, NADW and AAIW. The decomposition in base of the conservative variables was obtained through a perturbation process similar to that done for the SWMs properties (see subsection 2.4), considering a variation in the values of $\theta$ and $S$ within a normal distribution. In this manner, CDW should be composed of 65\% AABW, 30\% NADW and 5\% AAIW (Table 2), which is in quite good agreement with the values obtained by Broecker et al. (1985), except for the relative percentage of AAIW (CDW defined by Broecker et al. (1985) is warmer than CDW defined here). Using different conservative variables as reference and, most of all, the differences existing in the definition of AAIW and NADW, could be the reason for such differences in the composition of CDW with respect to the results obtained by Broecker et al. (1985). The decomposition rates of CDW suggest the total volume of the SO to be $51 \pm 2 \%$ occupied by AABW and $28 \pm 0.8 \%$ by NADW (Table 2 ). These results are also comparable with those obtained by Johnson (2008). Again, the different definition of the SWMs could be 
the reason that lies behind the differences between the results. The volume ratio AABW/NADW gives a value of $1.79 \pm 0.031$, which is very similar to the one of 1.74 obtained by Johnson (2008) and inside the range of variability (1-3) that this author established in his conclusions. This ratio was also obtained through perturbations considering the variability of the composition rates in CDW due to variations in $\theta$ and $\mathrm{S}$ and the uncertainties in $X_{C D W}, X_{A A B W}$ and $X_{N A D W}$. When the ratio AABW/NADW is calculated for the Atlantic $\left(70^{\circ} \mathrm{W}-80^{\circ} \mathrm{E}\right)$, Indian $\left(80-160^{\circ} \mathrm{E}\right)$, and Pacific $\left(160^{\circ} \mathrm{E}-70^{\circ} \mathrm{W}\right)$ sectors of the SO (Orsi et al., 1999), the values obtained are 2.42, 1.51 and 1.39, respectively. These values indicate a progressive decrease in the amount of AABW with respect to NADW, from the Atlantic Ocean eastwards toward the Pacific basin, a feature that is also highlighted from the results from Johnson (2008). It should be noted that the increase in the amount of NADW in the Pacific and Indian sectors $(\sim 15 \%$ of the volume in both sectors including CDW and $\sim 31 \%$ of the volume of each sector when CDW is decomposed, Table 2) with respect to the Atlantic Sector $(10 \pm 2 \%$ including CDW and $25 \pm 8 \%$ decomposing CDW, Table 2), could be related to the differences in the latitudinal position of the SAF in the three major oceans. In the Atlantic sector, the great volume of AABW displaces the SAF northwards, whereas in the Pacific and Indian sectors the volume of bottom waters is much lower than in the Atlantic and the SAF is located close to the shelf.

Following the separation of the SO into the three different sectors and including the volume of $\mathrm{CDW}$, the amount of $\mathrm{AABW}$ with respect to the volume of each sector is $27 \pm 0.2 \%$ in the Atlantic, $12 \pm 0.3 \%$ in the Indian and $8 \pm 0.2 \%$ in the Pacific sector. These are quite different from those obtained by Orsi et al. (1999; $71 \%, 14 \%$, and $15 \%$ respectively). The difference between the results could be due to the different methodologies used, because Orsi et al. (1999) estimated the volumes from water masses enclosed between neutral density layers. As an additional result, an estimation of the ventilation time for AABW can be deduced. Considering the AABW ventilation rate of $5.4 \mathrm{~Sv}$ established by Orsi et al., (2002) and the volume of AABW calculated for the SO $\left(3.9 \pm 0.2 \times 10^{16} \mathrm{~m}^{3}\right.$, Table 2$)$, a ventilation time of $\sim 240$ years can be estimated for AABW. When this quantity is calculated for the Atlantic sector with an associated ventilation rate of $3.3 \mathrm{~Sv}$, according to Orsi et al. (2002), it results in a ventilation time of $\sim 250$ years. Thus, the ventilation of the bottom ocean waters from Antarctic sources is mainly controlled by the shelf processes and the place where the largest volume of AABW is generated (AABW is $77 \%$ composed of WSBW, Table 2) ventilates at a period of time very similar to that of the whole SO.

\section{Conclusions}

An improved eOMP is performed in the SO taking into account the principal SWMs involved in the main circulation features of the SO. The implication of shelf waters and CDW in bottom waters formation is also considered. The eOMP analysis is quite realistic as the effects of the remineralisation of the organic matter $(\Delta O)$ and the dissolution of $\mathrm{CaCO}_{3}$ and opal $(\triangle C a)$ are included in the equations. This procedure allows $\mathrm{SiO}_{2}$ (an important property for Antarctic Bottom waters) and $\mathrm{A}_{\mathrm{T}}$ to be included as non-conservative variables. The use of mixing figures (groups of SWMs that intermix) in the methodology gives continuity and robustness to the eOMP analysis for two reasons. Firstly, the use of mixing figures allows the total number of SWMs to be more than the number of measured properties (equations) and secondly, the mixing figures change horizontally and vertically whilst moving in the TS-diagram but keep at least one 
SWM in common. The integrity of the results and a quite good agreement with the literature are shown. The total error of the analysis, the residuals of the properties and uncertainties of $X_{i}, \Delta O$ and $\triangle C a$ are quite low and illustrate the accuracy to the results.

The principal patterns of the thermohaline circulation of the SO can be identified from the $X_{i}$ distributions. The presence of CDW around the SO and the variability of its position in the water column with depth are clearly revealed. Importantly, the process of shoaling of CDW as it approaches the Antarctic shelf is described, which corroborates its implication in the processes of bottom water formation. The approach and shoaling of NADW and AAIW near to the Antarctic shelf is also illustrated. The important presence of AAIW and its close relationship with SAMW in the west Pacific coast vindicates the identification of this area as one of the places of AAIW formation. Near the coast, the presence of shelf waters (HSSW and AASW) in the deep layers is also in accordance with its implication in bottom water formation. Maxima values of $X_{W S B W}, X_{R S B W}$ are obtained in their respective zones of formation, i.e., the Weddell and Ross Seas. The results for $X_{A D L B W}$ show relatively high uncertainties, probably because its properties were defined in between those of WSBW and RSBW. The distributions of $\Delta O$ and $\triangle C a$ serve as tracers to distinguish between aged waters, where both terms take relatively high values, from recently ventilated waters, where both terms present low or close to zero values.

The volumetric census established from the results shows that the most voluminous SWMs in the $\mathrm{SO}$ are: $\mathrm{CDW}, \mathrm{AABW}, \mathrm{NADW}$ and AAIW, in this order, with percentages of $53 \pm 3 \%, 17 \pm$ $0.9 \%, 13 \pm 0.8 \%, 10 \pm 0.5 \%$, respectively. When CDW is decomposed in the respective contributions of AABW, NADW and AAIW, the percentages of composition (65\%, 30\% and $5 \%$, respectively) can be compared with those given by Broecker (1985). Furthermore, with respect to the total SO, the percentages of AABW and NADW (51 $\pm 2 \%$ and $28 \pm 0.8 \%$, respectively) are in quite good agreement with results from Johnson (2008). The ratio between the volumes of AABW and NADW is $1.79 \pm 0.03$. Considering the Atlantic, Pacific and Indian sectors (Orsi et al., 1999) separately, the volume occupied by AABW diminishes from the Atlantic $(60 \pm 0.2 \%)$, where the Weddell Sea is located (77\% of AABW is formed here) to the Pacific basin $(43 \pm 0.3 \%)$. This is because of the mixing that occurs on its way eastwards around the Antarctic continent (Orsi et al., 1999, Johnson, 2008). The analysis considers the three major types of bottom waters (WSBW, RSBW and ADLBW) instead of one general AABW and takes into account the presence of AASW and HSSW. This procedure permits much better the consideration of the complex processes of formation of bottom waters near the Antarctic continent and the determination of $\mathrm{AABW}$ properties in a more realistic manner. In fact, once AABW is obtained from the composition of its three major types, the uncertainties of $X_{A A B W}$ decrease to a mean value of 0.02 , while the mean values for the uncertainties of $X_{W S B W}, X_{A D L B W}$ and $X_{R S B W}$ are $0.05,0.07$ and 0.05 , respectively.

Therefore, these previous conclusions corroborate the agreement between the contributions of the obtained SWMs and the circulation of the SO. Thus, this improved eOMP analysis is shown to be a good tool with benefits for describing and estimating the mixing and distribution of SWMs in a certain region. Additionally, these results can also be of relevant use in climate studies. The SO is a very interesting area for climate research and most studies consider this ocean to be the most powerful place in $\mathrm{CO}_{2}$ uptake and distribution throughout the ocean. Thus, an estimation of the ventilation time of the bottom water masses formed in this ocean can be of great help. Taking into account the export rate of AABW of 5.4 Sv (Orsi et al., 2002) a ventilation time of $\sim 240$ years is estimated for the AABW. This ventilation time is very similar to that found when only considering the Atlantic sector ( 250 years), which means that the 
ventilation of the SO is related to the dynamics of the shelf processes and mainly controlled by processes, which take place in the principal zone of AABW formation, the Weddell Sea. This result could also give an idea of the time interval for the bottom ocean to respond to changes in the atmospheric anthropogenic gasses content.

\section{Acknowledgements}

We would extend our gratitude to the scientists and crew from the ships participating in the different cruises and collecting data for CARINA and GLODAP databases. This study was funded by the $7^{\text {th }}$ Framework Programme (EU FP CARBOCHANGE, C_ENVIR/0869) and by the Spanish Ministry of Education and Sciences through the Projects CATARINA (CTM201017141/MAR)

\section{APPENDIX: Error analyses: total error, residuals and uncertainties of $\mathrm{Xi}, \Delta \mathrm{O}$ and $\triangle \mathrm{Ca}$}

The total error of the eOMP analysis is almost zero from $500 \mathrm{~m}$ depth to the bottom (Fig. 8a), where the most volumetrically important SWMs are located. The residuals of the conservative variables $(\theta$ and $S$, Fig. $8 \mathrm{~b}$ ) present lower values than all the rest, as should be expected. $\theta$ and $\mathrm{S}$ show residuals near zero from $500 \mathrm{~m}$ depth to the bottom (SD of $\pm 0.010{ }^{\circ} \mathrm{C}$ for $\theta$ and \pm 0.004 for salinity, respectively) and considerably higher from $500 \mathrm{~m}$ up, where $\theta$ varies between \pm $0.038{ }^{\circ} \mathrm{C}$ and $\mathrm{S}$ between \pm 0.033 . The assumption of conservativeness is not justified in the surface because this layer is subject to seasonal variability. Nevertheless, as both variables present the highest weights in the analysis (Table 1), the majority of the positive residuals of $\theta$ in the surface-subsurface layer are compensated for by corresponding negative residuals of $\mathrm{S}$. The residuals of $\mathrm{NO}_{3}, \mathrm{PO}_{4}$ and $\mathrm{O}_{2}$ vary between $\pm 0.5, \pm 0.04$ and $\pm 3 \mu \mathrm{mol} \mathrm{kg}{ }^{-1}$, respectively, which are very similar to those of their respective accuracies (Table 1). The new term $(\triangle C a)$ added in the equations of $\mathrm{SiO}_{2}$ and $\mathrm{A}_{\mathrm{T}}$ helps to obtain better results in both variables. Thus, even though $\mathrm{SiO}_{2}$ and $\mathrm{A}_{\mathrm{T}}$ are the properties with lowest weights (Table 1) their predictability is as good as the other properties, with residuals varying between \pm 2.8 and $\pm 5 \mu$ mol $\mathrm{kg}^{-1}$, respectively (also very close to their accuracies).

Uncertainties in the SWMs contributions $\left(X_{i}\right)$ can be computed from the results of the 100 perturbations performed and are represented for the SWMs, which mainly contribute to the thermohaline circulation of the SO, i.e., WSBW and RSBW at bottom layers and AAIW, NADW and CDW at intermediate and deep layers (Fig. 9). The average value of the uncertainties of $X_{R S B W}$ (Fig. 9a) is 0.05 but the uncertainties of $X_{R S B W}$ are clearly divided into two groups. A first group, formed by points located between 2000-5000 m depth shows a mean value of 0.14 in the uncertainties. Most of the points of this group present high values of $X_{R S B W}$ (bigger dots in the plot, Fig. 9a). A second group ( $>$ times bigger in size) with a mean value of 0.03 in the uncertainties can be distinguished. Points from all depths form this group and most of them present low values of $X_{R S B W}$. The average value of the uncertainties of $X_{W S B W}$ (Fig. 9a) is also 0.05 but values close to zero can be found between the subsurface layers and $1000 \mathrm{~m}$ depth and also around $5000 \mathrm{~m}$ depth. These points show high values of $X_{W S B W}$. The uncertainties of $X_{A D L B W}$ (not shown) present a similar average value (0.07) to those of the other two types of bottom waters. From intermediate to deep layers (Fig. 9b), the uncertainties of $X_{N A D W}, X_{A A I W}$ and $X_{C D W}$ show an average value of 0.01 and offer quite remarkable aspects in their distributions. 
The uncertainties of $X_{N A D W}$ and $X_{A A I W}$ achieve high values (as much as $\sim 0.04$ and $\sim 0.2$, respectively) in the first $\sim 1500 \mathrm{~m}$ of the water column and most of them (especially for AAIW) also show high values of $X_{N A D W}$ and $X_{A A I W}$. Nevertheless, the majority of the points show values of uncertainties very close to zero from there to deep layers but with relatively high values in the contributions. The uncertainties of $X_{C D W}$ cover a range from zero to 0.1 in the first $\sim 1500 \mathrm{~m}$ of the water column, in the same manner incidentally, as for NADW and AAIW but from these depths the uncertainties go down from values near zero to $\sim 0.05$. Points of high $X_{C D W}$ values can be found throughout the water column. The sparse distribution of the uncertainties of $X_{C D W}$ could be a consequence of its variable position in the water column, by effect of the changing bathymetry while it moves eastward and by the different processes of shoaling/deepening associated with its participation in water mass formation processes.

The uncertainties of $\Delta O$ and $\Delta C a$ (Fig. 9c) show mean values of $\sim 2 \mu \mathrm{mol} \mathrm{kg}{ }^{-1}$ and $\sim 1 \mu \mathrm{mol} \mathrm{kg}^{-1}$, respectively ( $\triangle O$ presents a mean value of $31 \mu \mathrm{mol} \mathrm{kg} \mathrm{kg}^{-1}$ while $8 \mu \mathrm{mol} \mathrm{kg}^{-1}$ is the mean value obtained for $\triangle \mathrm{Ca}$ ). Between $1500 \mathrm{~m}$ and $4500 \mathrm{~m}$ depth (Fig. 9c) both distributions present a relevant number of points with higher values of uncertainty than all the rest, achieving $\sim 5 \mu \mathrm{mol}$ $\mathrm{kg}^{-1}$ in the case of $\Delta C a$ and $\sim 15 \mu \mathrm{mol} \mathrm{kg}{ }^{-1}$ in the case of $\Delta O$. Additionally, all these points present important values of $\triangle O$ and $\triangle C a$.

\section{References}

Archambeau A.-S., Pierre C., Poisson A., Schauer B., 1998. Distributions of oxygen and carbon stable isotopes and CFC-12 in the water masses of the Southern Ocean at $30^{\circ}$ E from South Africa to Antarctica: Results of the Cival cruise. Journal of Marine Systems 17, 25-38.

Arrigo K.R., Van Dijken G.L., 2003. Phytoplankton dynamics within 37 Antarctic coastal polynyas. Journal of Geophysical Research 108(C8), 3271. doi:10.1029/2002JC001739.

Arrigo K.R., Van Dijken G.L., Long M., 2008. Coastal Southern Ocean: A strong anthropogenic $\mathrm{CO} 2$ sink. Geophysical Research Letters 35, L21602. doi:10.1029/2008GL035624

Belkin, I.M., Gordon, A.L., 1996. Southern Ocean fronts from the Greenwich meridian to Tasmania. Journal of Geophysical Research 101, 3675-3696.

Brea S., Álvarez-Salgado X.A., Álvarez M., Pérez F.F., Mémery L., 2004. Nutrient mineralization rates and ratios in the eastern South Atlantic. Journal of Geophysical Research 109, C05030. doi:10.1029/2003JC002051

Broecker, W.S., 1974. "NO" a conservative water mass tracer. Earth and Planetary Science Letters 23, 8761-8776.

Broecker, W.S., Takahashi, T., Takahashi, T., 1985. Sources and flow patterns of deep-ocean waters as deduced from potential temperature, salinity and initial phosphate concentration. Journal of Geophysical Research 90, 6925-6939.

Broecker, W.S., Sutherland, S., Smethie, W., Peng, T.-H., Ostlung, G., 1995. Oceanic radiocarbon: Separation of the natural and bomb components. Global Biogeochemical Cycles 9 (2), 263-288 
Budillon G., Gremes Cordero, S., Salusti, E., 2002. On the dense water spreading off the Ross Sea shelf (Southern Ocean). Journal of Marine Systems 35 (3-4), 207-227

Carmack, E.C., Killworth, P.D., 1978. Formation and interleaving of abyssal water masses off wilkes land, Antarctica. Deep-Sea Research 25 (4), 357-369.

Castro, C.G., Pérez F.F., Holley S.E., Ríos A.F., 1998. Chemical characterisation and modelling of water masses in the Northeast Atlantic. Progress in Oceanography 41, 249-279.

Coatanoan, C., Metzl, N., Fieux, M., Coste,B. 1999. Seasonal water mass distribution in the Indian throughflow entering the Indian Ocean. Journal of Geophysical Research 104, 2080120826.

Deacon, G.E.R., 1937. The hydrology of the Soutern Ocean. Discovery Report 15, 3-122

Deacon, G.E.R., 1984. The Antarctic Circumpolar Ocean. Studies in Polar Research. Cambridge University, Cambridge, 180pp.

Doney S.C., Bullister J.L., 1992. A Chlorofluorocarbon section in the eastern North Atlantic. Deep Sea Research Part A, 39, 1857-1883.

Fahrbach, E., Rohardt, G., Scheele, N., Schröder, M., Strass, V., Wisotzki, A., 1995. Formation and discharge of deep and bottom water in the northwestern Weddell Sea. Journal of Marine Research 53, 515-538

Foster T.D., Carmack, E.C., 1976. Frontal zone mixing and Antarctic Bottom Water formation in the southern Weddell Sea. Deep Sea Research 23, 301-307

Foster, T.D., 1995. Abyssal water mass formation off the eastern Wilkes Land coast of Antarctica. Deep Sea Research Part I, 42, 501-522.

Gill, A.E., 1973. Circulation and bottom water production in the Weddell Sea, Deep Sea Research 20, 111-140.

Gille, S.T., 1994. Mean sea-surface height of the Antarctic circumpolar current form GEOSAT data: Method and application. Journal of Geophysical Research 99 (C9), 18225-18273.

Gordon, A.L., Tchernia, P., 1972. Waters of the continental margin off Adélie Coast, Antarctica, in Antarctic Oceanology II: The Australian-New Zealand Sector, Antarct. Res. Ser., vol 19, edited by D.E. Hayers, pp. 59-69, AGU, Washington D.C., 1972.

Gordon, A.L., Huber, B.A., 1984. Thermohaline stratification below the Southern Ocean sea ice. Journal of Geophysical Research 89 (C1), 641-648

Gordon, A.L., Huber, B.A., 1990. Southern Ocean winter mixed layer. Journal of Geophysical Research 95 (C7), 11655-11672.

Gordon, A.L., Visbeck, M., Huber, B., 2001. Export of Weddell Sea Deep and Bottom Water. Journal of Geophysical Research 106, 9005-9017

Gordon, A.L., Zambianchi E., Orsi A., Visbeck M., Giulivi C.F., Whitworth III T., Spezie G., 2004. Energetic plumes over the western Ross Sea continental slope. Geophysical Research Letters 31, L21302. doi:10.1029/2004GL020785 
Hoppema, M., Fahrbach, K.-U. R., de Baar, H.J.W., Gerhard, K., 1998. Enrichment of silicate and $\mathrm{CO} 2$ and circulation of the bottom water in the Weddell Sea. Deep Sea Research I, 45, 1797-1817.

Hoppema, M., Velo, A., van Heuven, S., Tanhua, T., Key, R.M., Lin, X., Bakker, D.C.E., Pérez, F.F., Ríos, A.F., Lo Monaco, C., Sabine, C.L., Álvarez, M., Bellerby, R.G.J., 2009. Consistency of cruise data of the CARINA database in the Atlantic Sector of the Southern Ocean, Earth Systems Science Data 1, 63-75. doi: 10.5194/essd-1-63-2009

Iudicone D., Madec, G., Blanke, B. and Specih, S. 2008. The role of Southern Ocean surface forcings and mixing in the global conveyor. Journal of Physical Oceanography 38, 1377-1400

Jacobs, S.S., Amos A.F., Bruchhau P.M., 1970. Ross Sea oceanography and Antarctic Bottom Water formation, Deep Sea Research 17, 935-962.

Jacobs, S.S., Fairbanks R.G., Horibe Y., 1985. Origin and evolution of water masses near the Antarctic continental margin: Evidence form $\mathrm{H} 218 \mathrm{O} / \mathrm{H} 216 \mathrm{O}$ ratios in seawater, in Oceanology of the Antarctic Continental Shelf, Ant. Res. Ser., vol 43, edited by S.S. Jacobs, pp. 59-85, AGU, Washington D.C.

Jacobs, S.S., 1989. Marine controls on modern sedimentation on the Atnarctic continental-shelf. Marine Geology 85 (2-4), 121-153.

Johnson, G,C,, 2008. Quantifying Antarctic Bottom Water and North Atlantic Deep Water volumes. Journal of Geophysical Research 113, C05027. doi:10.1029/2007JC004477

Kawabe, M., Fujio, F., 2010. Pacific Ocean Circulation Based on Observation. Journal of Oceanography 66, 389-403

Key, R. M., Kozyr, A., Sabine, C. L., Lee, K., Wanninkhof, R., et al., 2004. A global ocean carbon climatology: Results from Global Data Analysis Project (GLODAP). Global Biogeochemical Cycles 18, GB4031. doi:10.1029/2004GB002247.

Lazier, J.R.N., 1973. The renewal of Labrador Sea Water, Deep Sea Research 20, 341-353.

Locarnini, R.A. 1994. Water masses and circulation in the Ross Gyre and environs. Ph.D. Dissertation, Texas A\&M University, College Station.

Lo Monaco, C., Metzl, N., Poisson, A., Brunet, C., Schauer, B. 2005. Anthropogenic CO2 in the Southern Ocean: Distribution and inventory at the Indian-Atlantic boundary (World Ocean Circulation Experiment line I6)

Lo Monaco, C., Álvarez, M., Key, R.M., Lin, X., Tanhua, T., Tillbrook, B., Bakker, D.C.E., van Heuven, S., Hoppema, M., Metzl, N., Ríos, A.F., Sabine, C.L., Velo, A., 2010. Asssesing the internal consistency of the CARINA database in the Indian sector of the Southern Ocean, Earth Systems Science Data 2, 51-70. doi:10.5194/essd-2-51-2010.

Lumpkin, R. and Speer, K. 2007. Global ocean meridional overturning, Journal of Physical Oceanography 37, 2550-2562.

Mackas, D.L., Denman, L., Bennett, A.F., 1987. Least Squares Multiple Tracer Analysis of Water Mass Composition. Journal of Geophysical Research 92, C3, 2907-2918. 
Mantisi, F., Beauverger C., Poisson A., Metzl N., 1991. Chlorofluoromethanes in the western Indian sector of the Southern Ocean and their relations with geochemical tracers. Marine Chemistry 35, 151-167.

McCartney, M.S., 1977. Subantarctic mode water, in A Voyage of Discovery, George Deacon $70^{\text {th }}$ Anniversary Volume, edited by M. Angel, pp. 103-119, Pergamon, Oxford, U.K.

McCarteney, M.S., 1982. The subtropical recirculation of mode water. Journal of Marine Research 40 (Suppl.), 427-464

Meredith M.P., Watson A.J., Van Scoy K.A., Haine T.W.N., 2001. Chlorofluorocarbon-derived formation rates of the deep and bottom waters of the Weddell Sea. Journal of Geophysical Research 106, 2899-2919.

Naveira Garabato, A.C., Ferrari R., Polzin, K.L., 2011. Eddy stirring in the Southern Ocean. Journal of Geophysical Research 116 (C09019). doi:10.1029/2010JC006818

Newsom K., Francavillese L., Tierney J., 1965. Oceanography in operation deep freeze 62, 1961-1962. US Naval Oceanographic Office, Marine Geophysical Investigations, Technical Report TR-118, Washington DC, unpublished.

Orsi, A.H., Whitworth III, T., Nowlin, W.D., 1995. On the meridional extent and fronts of the Antarctic Circumpolar Current. Dep Sea Research I, 42(5): 641-673

Orsi, A.H., Johnson G.C., Bullister J.L., 1999. Circulation, mixing, and production of Antarctic Bottom Water. Progress in Oceanography, 43, 55-109. Doi: 10.1016/S0079-6611(99)00004-X.

Orsi, A.H., Jacobs, S.S., Gordon, A.L., Visbeck, M., 2001. Cooling and ventilating the abyssal ocean. Geophysical Research Letters 28, 2923-2926, doi:10.1029/2001GL012830

Orsi A.H., Smethie Jr. J., Bullister J.L., 2002. On the total input of Antarctic waters to the deep ocean: A preliminary estimate from chlorofluorocarbon measurements. Journal of Geophysical Research 107 (C8), 3122. doi:10.1029/2001JC000976.

Orsi, A.H., Wiederwohl, C.L. 2009. A recount of Ross Sea waters. Deep Sea Research Part II, 56, 778-795.

Padman L., Howard, S.L., Orsi, A.H., Muench, 2008. Tides of the northwestern Ross Sea and their impact on dense outflows of Antarctic Bottom Water. In: Gordon, A., Padman, L., Bergamasco, A. (Eds.) Depp Sea Research II. doi:10.1016/jdsr2.2008.10.026.

Piola, A.R., Gordon, A.L., 1989. Intermediate waters in the southwest South Atlantic. Deep Sea Research Part II 36, 1-16.

Poole, R., Tomczak, M., 1999. Optimum multiparameter analysis of the water mass structure in the Atlantic Ocean thermocline. Deep Sea Research I 46, 1895-1921

Ribbe, J. 1999. On wind-driven mid-latitude convection in ocean general circulation models. Tellus 51A, 505-516 
Rintoul, S.R., 1998. On the origin and influence of Adélie Land Bottom Water. In S.S. Jacobs \& R. F. Weiss (Eds.), Interactions at the Antarctic Continental Margins, (Vol. 5, 151-171) Antarctic Research Series. Washington, DC: American Geophysical Union.

Rintoul S.R., Bullister J.L., 1999. A late winter hydrographic section from Tasmania to Antarctica. Depp Sea Research I 46, 1417-1454.

Rintoul, S.R., Hughes W.C., and Olbers D., 2001. The Antarctic Circumpolar Current system, in Ocean Circulation and Climate, edited by G. Siedler, J. Church, and J. Gould, 271-300. Elsevier, New York.

Rios, A.F., Anderson T.R., Pérez F.F., 1995. The carbonic system distribution and fluxes in the NE Atlantic during Spring 1991. Progress in Oceanography 35, 295-314

Rubin, S.I., 2002. Separating natural and bomb-produced radiocarbon in the ocean: The potential alkalinity method. Global Biogeochemical Cycles, 16 (4) 1105. doi:10.1029/2001GB001432

Sabine, C.L., Hoppema, M., Key, R.M., Tilbrook, B., van Heuven, S., Lo Monaco, C., Metzl, N., Ishii, M., Murata, A., and Musielewicz, S., 2009. Assessing the internal consistency of the CARINA data base in the Pacific sector of the Southern Ocean, Earth Systems Science Data 2, 555-578. doi:10.5194/essdd-2-555-2009.

Sloyan, B.M., and Rintoul, S.R., 2001. The Southern Ocean limb of the global deep overturning circulation. Journal of Physical Oceanography 31, 143-173

Smethie, W.M. Jr., 1993. Tracing the thermohaline circulation in the western North Atlantic using chlorofluorocarbons, Progress in Oceanography 31, 51-99.

Smith, N.R., Zhaoqian, D., Kerry, K.R., Wright, S., 1984. Water masses and circulation in the region of Prydz Bay, Antarctica. Deep Sea Research 31, 1121-1147.

Talley L.D., McCartney M.S., 1982. Distribution and circulation of Labrador Sea water. Journal of Physical Oceanography 12, 1189-1205.

Talley, L.D., 1996: Antarctic Intermediate Water in the South Atlantic. The South Atlantic: Present and Past Circulation, G. Wefer et al., Eds., Springer, 219-238.

Talley, L.D., 2003. Shallow, intermediate and deep overturning components of the global heat budget. Journal of Physical Oceanography 33, 530-560

Talley, L.D., 2007. Hydrographic Atlas of the World Ocean Circulation Experiment (WOCE). Volume 2: Pacific Ocean. International WOCE Project Office, Southampton.

Thompson, R.O.R.Y., Edwards, R.J., 1981. Mixing and water-mass formation in the Australian Subantactic. Journal of Physical Oceanography 11, 1399-1406

Tomczak, M., 1981. A multi-parameter extension of temperature/salinity diagram techniques for the analysis of non-isopycnal mixing. Progress in Oceanography 10, 147-171.

Tomczak, M., Large, D.G.B., 1989. Optimum multiparameter analysis of mixing in the thermocline of the eastern Indian Ocean, Journal of Geophysical Research 94, 16141-16149 
Tomczak M., Liefrink S., 2005. Interannual variations of wáter mass volumes in the Southern Ocean. Journal of Atmospheric and Ocean Science, 10, 1, 31-42. doi:10.1080/17417530500062838

Velo A., Vázquez-Rodríguez M, Padín X.A., Gilcoto M., Ríos A., Pérez F.F., 2010. A multiparametric method of interpolation using WOA05 applied to anthropogenic CO2 in the Atlantic. Scientia Marina 74(S1), 21-32. doi: 10.3989/scimar.2010.74s1021

Weiss, R.F., Östlung, G., Craig, H., 1979. Geochemical studies of the Weddell Sea. Deep Sea Research 26, 1093-1120

Williams G.D., Aoki S., Jacobs S.S., Rintoul S.R., Tamura T., Bindoff N.L., 2010. Antarctic Bottom Water from the Adélie and George V Land coast, East Antarctica (140-149 $\mathrm{E}$ ). Journal of Geophysical Research 115, C04027. doi:10.1029/2009JC005812

Withworth III, Orsi A.H., Kim S.-J., Nowlin Jr.,W.D., Locarnini, R.A., 1998. Water masses and mixing near the Atnarctic Slope Front. In: Jacobs, SS., Weiss, R.F. (Eds), Ocean, Ice and Atmosphere: Interactions at the Antarctic Continental Margin. AGU, Washington, DC, pp. 1-27.

Whitworth, T., III, Orsi, A.H., 2006. Antarctic Bottom Water production and export by tides in the Ross Sea. Geophysical Research Letters 33, L12609. doi:10.1029/2006GL026357

Worthington L.V., 1981. The water masses of the world ocean: Some results of a fine-scale census, in Evolution of Physical Oceanography: Scientific Surveys in Honor of Henry Stommel, edited by B.A. Warren and C. Wunsch, chap. 2, 42-69, MIT Press, Cambridge, Mass.

Wüst, G., 1935. Schichtung und Zirculation des Atlantischen Ozeans, Die Stratosphäre. Wissenschaftliche Ergebnisse der Deutschen Atlantischen Expedition auf dem Froschung und Vermessunsschiff "Meteor" 6 (1), 99-188.

You, Y., Tomczak, M., 1993.Thermocline circulation and ventilation in the Indian Ocean derived from water mass analysis. Deep Sea Research Part I 40, 13-56.

You, Y., 1997. Seasonal variations of themocline circulation and ventilation in the Indian Ocean, Journal of Geophysical Research 102, 10391-10422. 


\section{Tables and Figures}

\begin{tabular}{|c|c|c|c|c|c|c|c|c|c|}
\hline & $\begin{array}{c}\text { Potential } \\
\text { Temperature } \\
(\theta)\end{array}$ & Salinity (S) & $\begin{array}{l}\text { Nitrate } \\
\left(\mathrm{NO}_{3}{ }^{\circ}\right)\end{array}$ & $\begin{array}{c}\text { Phosphate } \\
\left(\mathrm{PO}_{4}{ }^{\circ}\right)\end{array}$ & $\begin{array}{c}\text { Oxygen } \\
\left(\mathrm{O}_{2}{ }^{\circ}\right)\end{array}$ & NO & $P O$ & $\begin{array}{l}\text { Silicate } \\
\left(\mathrm{SiO}_{2}{ }^{\circ}\right)\end{array}$ & $\begin{array}{c}\text { Total } \\
\text { Alkalinity } \\
\left(A_{T}^{o}\right)\end{array}$ \\
\hline & ${ }^{\circ} \mathrm{C}$ & psu & & \multicolumn{6}{|c|}{$\mu \mathrm{molkg}{ }^{-1}$} \\
\hline STCW & $15.000 \pm 0.005$ & $35.660 \pm 0.005$ & $2.34 \pm 0.05$ & $0.250 \pm 0.005$ & $237 \pm 2$ & $259 \pm 5$ & $271 \pm 5$ & $0.50 \pm 0.01$ & $2340 \pm 6$ \\
\hline SAMW1 & $8.750 \pm 0.005$ & $34.580 \pm 0.005$ & $13.6 \pm 0.3$ & $0.95 \pm 0.02$ & $283 \pm 3$ & $410 \pm 8$ & $412 \pm 8$ & $3.00 \pm 0.06$ & $2290 \pm 6$ \\
\hline SAMW2 & $5.000 \pm 0.005$ & $34.140 \pm 0.005$ & $21.2 \pm 0.4$ & $1.48 \pm 0.03$ & $299 \pm 3$ & $497 \pm 10$ & $499 \pm 10$ & $7.0 \pm 0.1$ & $2270 \pm 6$ \\
\hline HSSW & $-1.910 \pm 0.005$ & $34.820 \pm 0.005$ & $28.5 \pm 0.6$ & $1.96 \pm 0.04$ & $300 \pm 3$ & $565 \pm 11$ & $565 \pm 11$ & $85 \pm 2$ & $2360 \pm 6$ \\
\hline AASW & $-1.850 \pm 0.005$ & $33.800 \pm 0.005$ & $24.5 \pm 0.5$ & $1.70 \pm 0.03$ & $388 \pm 4$ & $616 \pm 12$ & $617 \pm 12$ & $40.0 \pm 0.8$ & $2290 \pm 6$ \\
\hline AAIW & $3.140 \pm 0.005$ & $34.140 \pm 0.005$ & $25.2 \pm 0.5$ & $1.74 \pm 0.03$ & $305 \pm 3$ & $540 \pm 11$ & $541 \pm 11$ & $15.0 \pm 0.3$ & $2278 \pm 6$ \\
\hline NADW & $3.280 \pm 0.005$ & $34.910 \pm 0.005$ & $22.6 \pm 0.4$ & $1.55 \pm 0.03$ & $220 \pm 2$ & $431 \pm 9$ & $430 \pm 9$ & $30.0 \pm 0.6$ & $2334 \pm 6$ \\
\hline$C D W$ & $0.650 \pm 0.005$ & $34.707 \pm 0.005$ & $30.7 \pm 0.6$ & $2.12 \pm 0.04$ & $218 \pm 2$ & $504 \pm 10$ & $504 \pm 10$ & $100 \pm 2$ & $2348 \pm 6$ \\
\hline$R S B W$ & $-0.250 \pm 0.005$ & $34.695 \pm 0.005$ & $30.7 \pm 0.6$ & $2.13 \pm 0.04$ & $236 \pm 2$ & $522 \pm 10$ & $524 \pm 10$ & $105 \pm 2$ & $2352 \pm 6$ \\
\hline ADLBW & $-0.470 \pm 0.005$ & $34.683 \pm 0.005$ & $33.5 \pm 0.7$ & $2.24 \pm 0.04$ & $238 \pm 2$ & $550 \pm 11$ & $540 \pm 11$ & $130 \pm 3$ & $2352 \pm 6$ \\
\hline WSBW & $-0.900 \pm 0.005$ & $34.650 \pm 0.005$ & $31.1 \pm 0.6$ & $2.16 \pm 0.04$ & $266 \pm 3$ & $556 \pm 11$ & $558 \pm 11$ & $105 \pm 2$ & $2345 \pm 6$ \\
\hline$A A B W *$ & $-0.753 \pm 0.005$ & $34.660 \pm 0.005$ & $31.1 \pm 0.6$ & $2.16 \pm 0.04$ & $259 \pm 3$ & $550 \pm 11$ & $549 \pm 11$ & $106 \pm 2$ & $2347 \pm 6$ \\
\hline Weights & 20 & 10 & 1 & 1 & 1 & 1 & 1 & 0.2 & 0.1 \\
\hline$r^{2}$ & 0.99 & 0.99 & 0.97 & 0.97 & 0.99 & 0.94 & 0.93 & 0.99 & 0.96 \\
\hline SEE & 0.02 & 0.02 & 0.55 & 0.04 & 2.7 & 7.2 & 7.2 & 2.9 & 6 \\
\hline SEE / $\varepsilon$ & 4 & 3 & 1 & 1 & 1 & 1 & 1 & 1 & 1 \\
\hline
\end{tabular}

Table 1. Main properties of each of the Source Water Masses (SWMs) considered in the study with correspondent accuracies $(\varepsilon)$. The properties of AABW* are those obtained from its composition into 76\% WSBW, 20\% RSBW and 3\% ADLBW. The correspondent weights of each property equation in the extended OMP (eOMP) analysis are also given, together with the square of correlation coefficients $\left(\mathrm{r}^{2}\right)$ between the observed and estimated properties, the Standard Errors of the Estimates and the SEE/ $\mathcal{E}$ ratios. 


\begin{tabular}{|c|c|c|c|c|c|}
\hline \multirow[b]{2}{*}{$\begin{array}{c}\text { so volume } \\
23.8 \cdot 10^{16} \mathrm{~m}^{3}\end{array}$} & \multirow[b]{2}{*}{$\begin{array}{c}\text { Volume } \\
10^{16} \mathrm{~m}^{3}\end{array}$} & \multicolumn{4}{|c|}{$\%$} \\
\hline & & so & Atlantic & Indian & Pacific \\
\hline WSBW & $3.0 \pm 0.3$ & $13 \pm 1$ & $26 \pm 0.2$ & $9 \pm 0.4$ & $0.2 \pm 0.3$ \\
\hline RSBW & $0.8 \pm 0.09$ & $3 \pm 0.4$ & $0.2 \pm 0.002$ & $2 \pm 0.002$ & $7 \pm 0.001$ \\
\hline$A D L B W$ & $0.1 \pm 0.03$ & $0.5 \pm 0.1$ & $0.1 \pm 0.004$ & $1 \pm 0.01$ & $0.8 \pm 0.005$ \\
\hline NADW & $3.0 \pm 0.2$ & $13 \pm 0.8$ & $10 \pm 2$ & $15 \pm 3$ & $15 \pm 2$ \\
\hline AAIW & $2.5 \pm 0.1$ & $10 \pm 0.5$ & $9 \pm 5$ & $11 \pm 8$ & $13 \pm 4$ \\
\hline$C D W$ & $12.6 \pm 0.6$ & $53 \pm 3$ & $51 \pm 6$ & $54 \pm 8$ & $53 \pm 6$ \\
\hline $\begin{array}{c}\text { STCW + } \\
\text { SAMW }\end{array}$ & $1.4 \pm 0.08$ & $6 \pm 0.4$ & $1.3 \pm 0.5$ & $7 \pm 7$ & $10 \pm 6$ \\
\hline $\begin{array}{c}\text { HSSW }+ \\
\text { AASW }\end{array}$ & $0.4 \pm 0.02$ & $1.5 \pm 0.07$ & $2.4 \pm 1$ & $1 \pm 1$ & $1 \pm 1$ \\
\hline$A A B W$ & $3.9 \pm 0.2$ & $17 \pm 1$ & $27 \pm 0.2$ & $12 \pm 0.3$ & $8 \pm 0.2$ \\
\hline$A A B W *$ & $12.1 \pm 0.3$ & $51 \pm 2$ & $60 \pm 0.2$ & $47 \pm 0.4$ & $43 \pm 0.3$ \\
\hline$N A D W *$ & $6.7 \pm 0.2$ & $28 \pm 1$ & $25 \pm 8$ & $31 \pm 3$ & $31 \pm 2$ \\
\hline \multirow[t]{2}{*}{$A A I W *$} & $3.2 \pm 0.1$ & $13 \pm 0.5$ & $11 \pm 5$ & $13 \pm 8$ & $15 \pm 4$ \\
\hline & \multicolumn{5}{|c|}{ Composition } \\
\hline $\begin{array}{l}A A B W \\
C D W\end{array}$ & \multicolumn{5}{|c|}{$\begin{array}{c}77 \% \text { WSBW + } 20 \% \text { RSBW + 3\% ADLBW } \\
65 \% \text { AABW + 30\% NADW + 5\% AAIW }\end{array}$} \\
\hline
\end{tabular}

Table 2. Volumes occupied by the different SWMs present in the SO and the amount (\%) with respect to the total volume of the SO $\left(2.38 \cdot 10^{17} \mathrm{~m}^{3}\right)$. AABW results from the sum of the volumes of WSBW, RSBW and ADLBW. AABW*, NADW* and AAIW* refer to the volume occupied by each of them when CDW is decomposed into AABW, NADW and AAIW. The compositions of AABW and CDW are also shown below the volumes and percentages. 


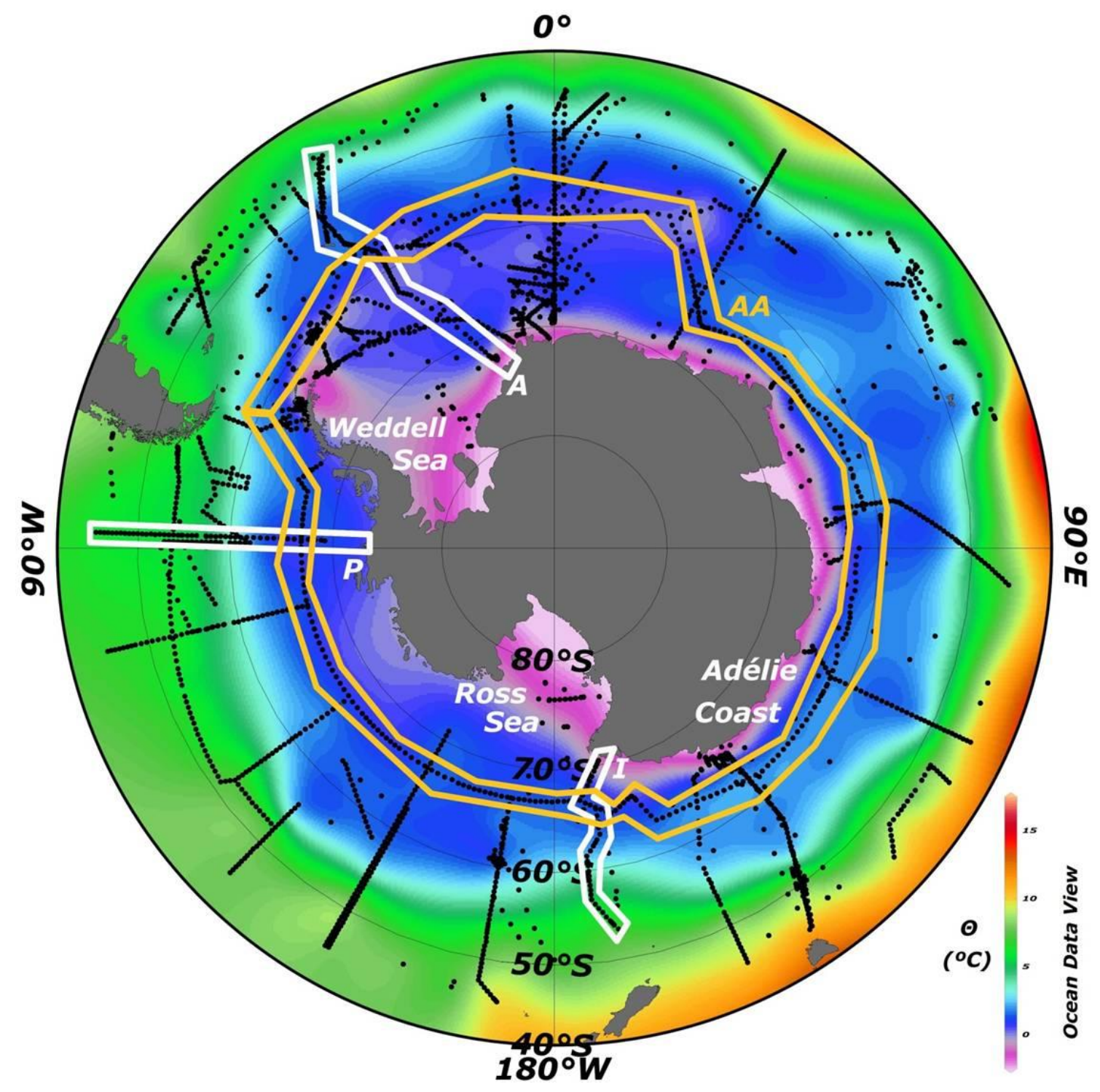

Figure 1. Depth integrated Potential Temperature $\left(\theta\right.$, in $\left.{ }^{\circ} \mathrm{C}\right)$ with the measured points downloaded from CARINA and GLODAP databases (black circles). The locations of the three formation zones of the bottom waters (Weddell Sea, Ross Sea and Adélie Coast in white text) together with the surrounding section AA (yellow lines) and the meridional A, P, and I sections (white lines) are also shown. 


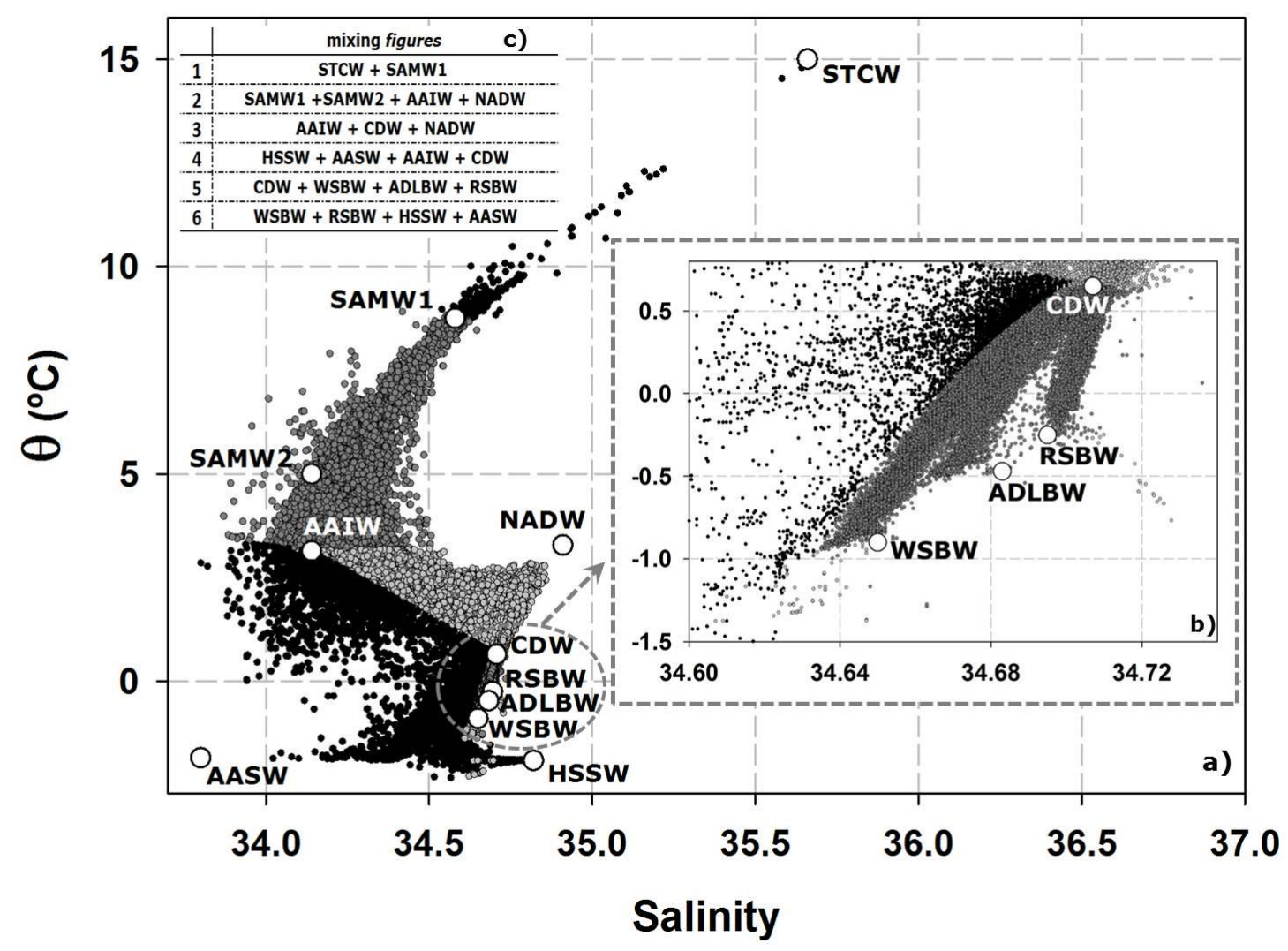

Figure 2. TS-diagram a) of data including the defining points of the SWMs used in the analysis and b) zoomed for bottom waters (WSBW, ADLBW and RSBW) and CDW. The SWMs included in the different mixing figures are shown in the table c) located in the top-left part of the plot.

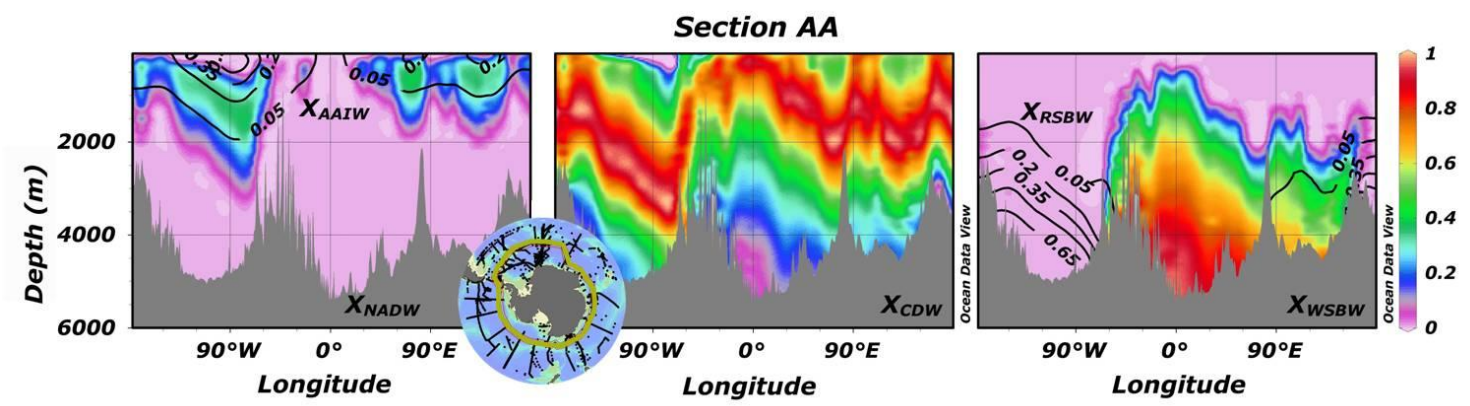

Figure 3. Section AA surrounding the SO. The map between plots a) and b) shows the location of the section. In each plot, the distributions of a) $X_{A A I W}$ and $X_{N A D W}$, b) $X_{C D W}$, c) $X_{R S B W}$ and $X_{W S B W}$ with depth are shown. The names of the SWMs lying over the bathymetry correspond to the coloured plots, whereas the names inside the plot correspond to the contoured plots. 


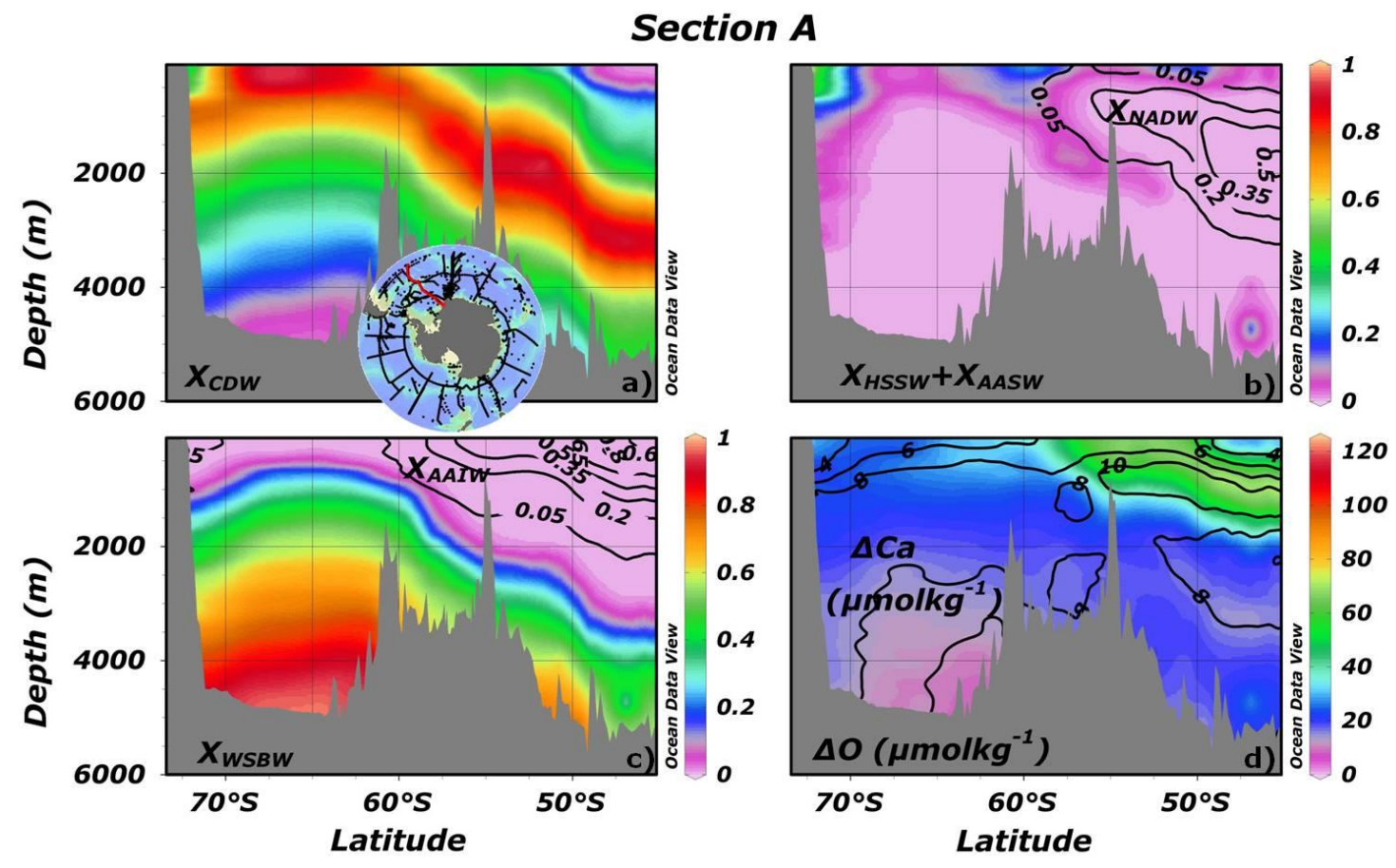

Figure 4. Meridional Section A. The map over the plot a) shows the location of the section. In each plot, the distributions of a) $X_{C D W}$, b) $X_{H S S W}+X_{A A S W}$ and $X_{N A D W}$, c) $X_{W S B W}$ and $X_{A A I W}$, d) $\triangle C a$ and $\Delta O$ are shown. The names of the SWMs lying over the bathymetry correspond to the coloured plots, whereas the names inside the plot correspond to the contoured plots.

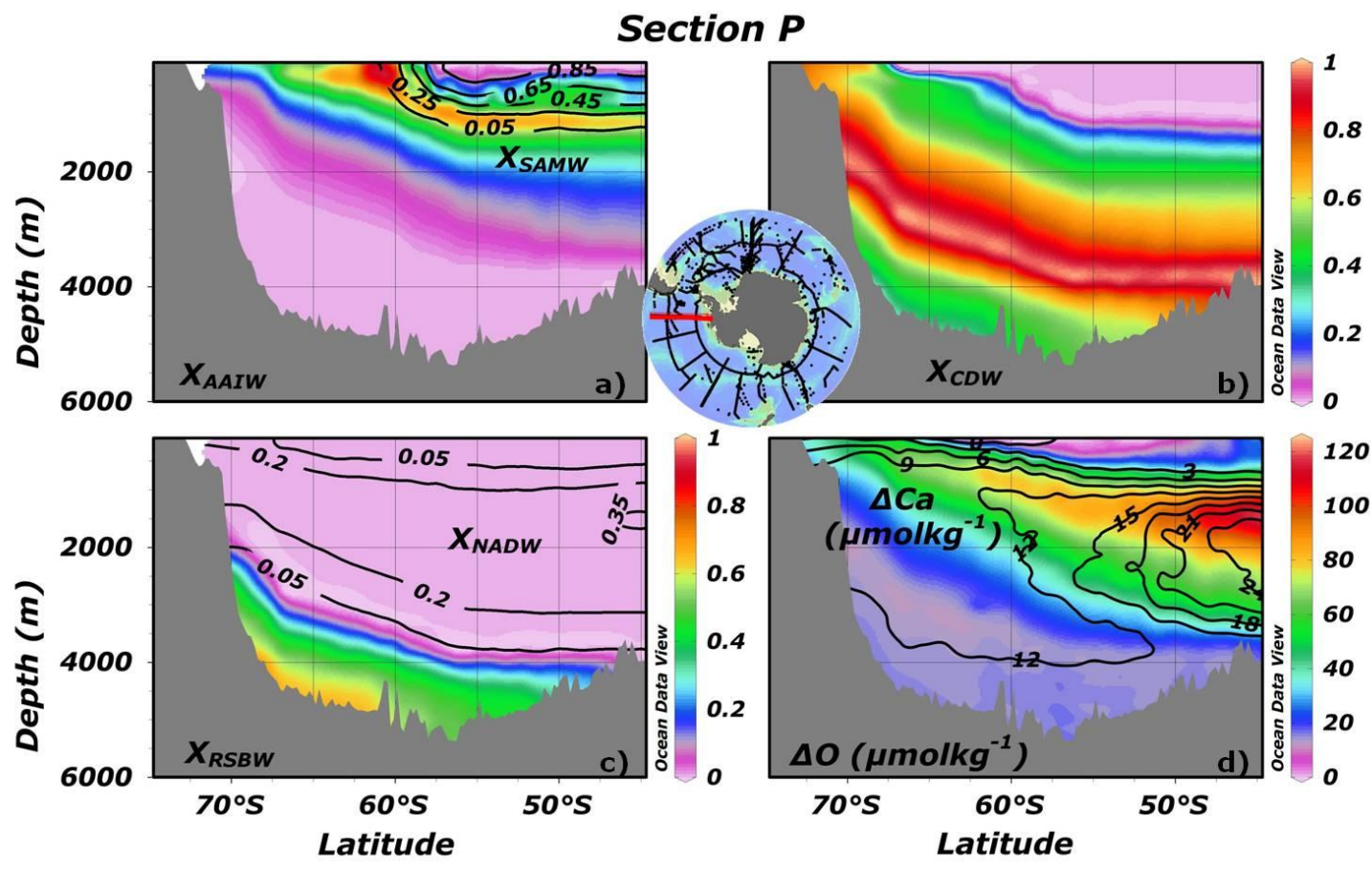

Figure 5. Meridional Section P. The map between plots a) and b) shows the location of the section. In each plot, the distributions of a) $X_{A A I W}$ and $X_{S A M W}$, b) $X_{C D W}$, c) $X_{R S B W}$ and $X_{N A D W}$, d) $\triangle C a$ and $\Delta O$ with depth are shown. The names of the SWMs lying over the bathymetry correspond to the coloured plots, whereas the names inside the plot correspond to the contoured plots. 


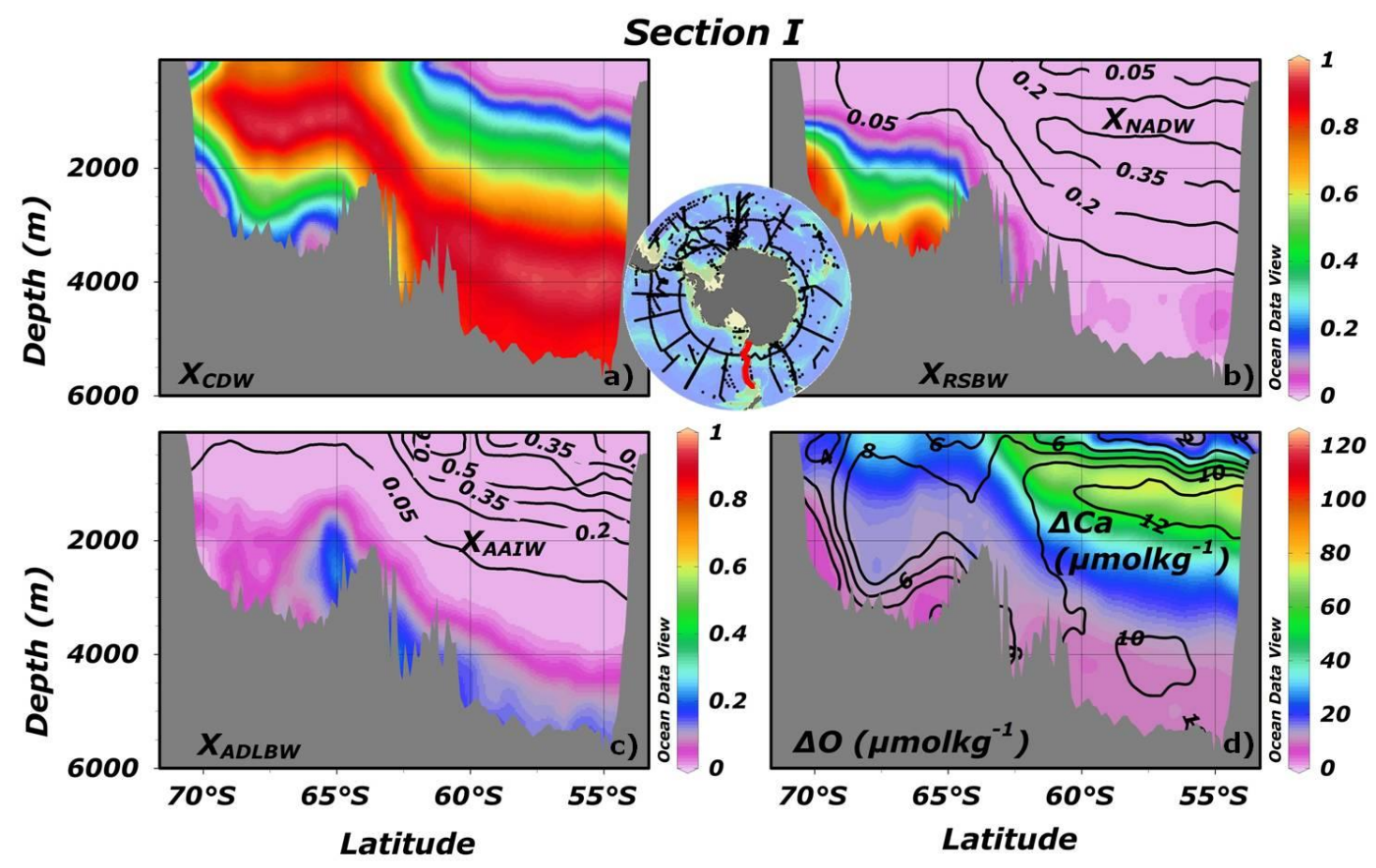

Figure 6. Meridional Section I. The map between plots a) and b) shows the location of the section. In each plot, the distributions of a) $X_{C D W}$, b) $X_{R S B W}$ and $X_{N A D W}$, c) $X_{A D L B W}$ and $X_{A A I W}$, d) $\triangle C a$ and $\triangle O$ with depth are shown. The names of the SWMs lying over the bathymetry correspond to the coloured plots, whereas the names inside the plot correspond to the contoured plots.
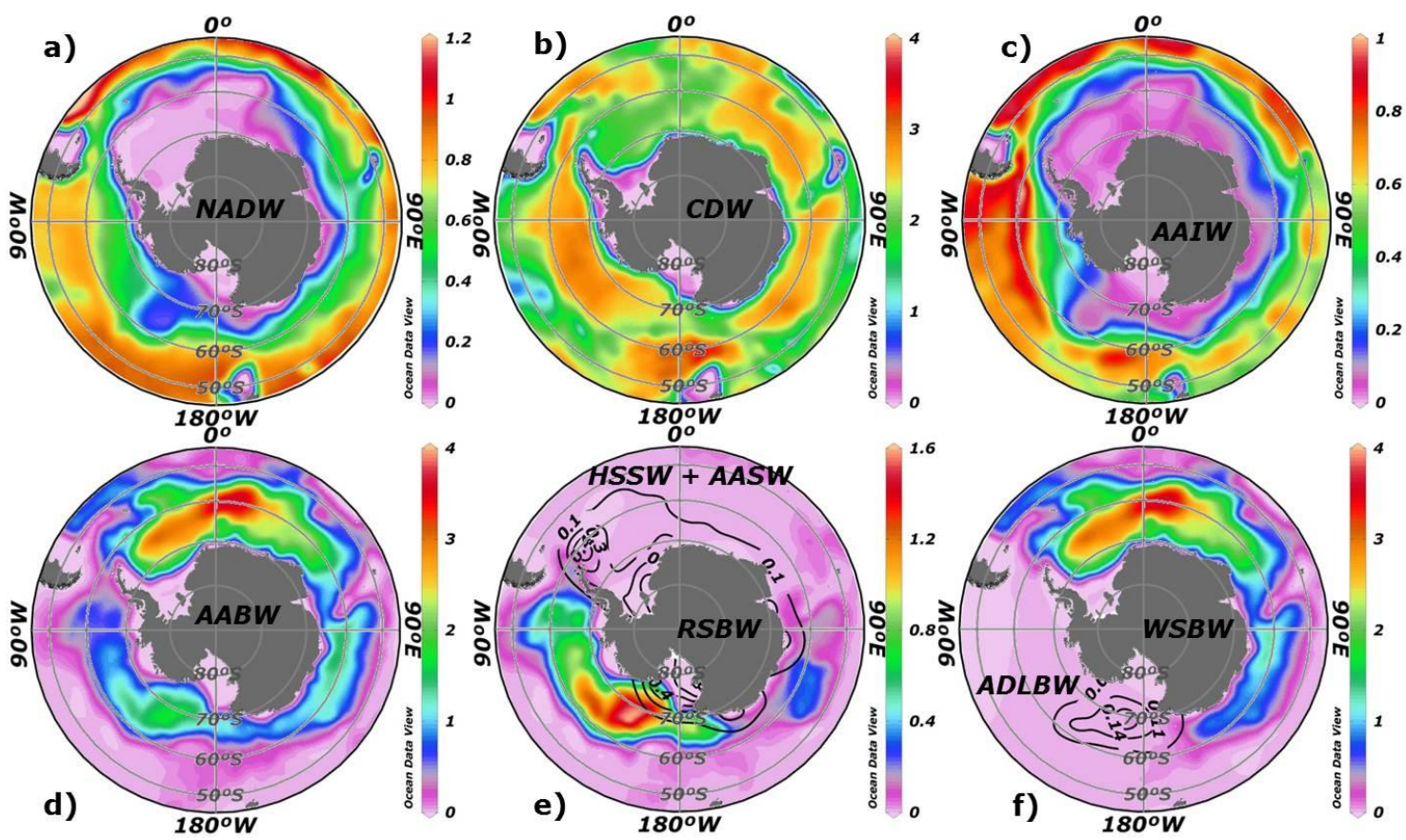

Figure 7. Thickness (in $10^{3} \mathrm{~m}$ ) of a) NADW, b) CDW, c) AAIW, d) AABW (=WSBW + RSBW + ADLBW), e) RSBW and HSSW + AASW, f) WSBW and ADLBW in their different areas of distribution within the SO. The text over the Antarctic continent corresponds to the coloured plots, whereas the text inside the plot corresponds to the contoured plots. 

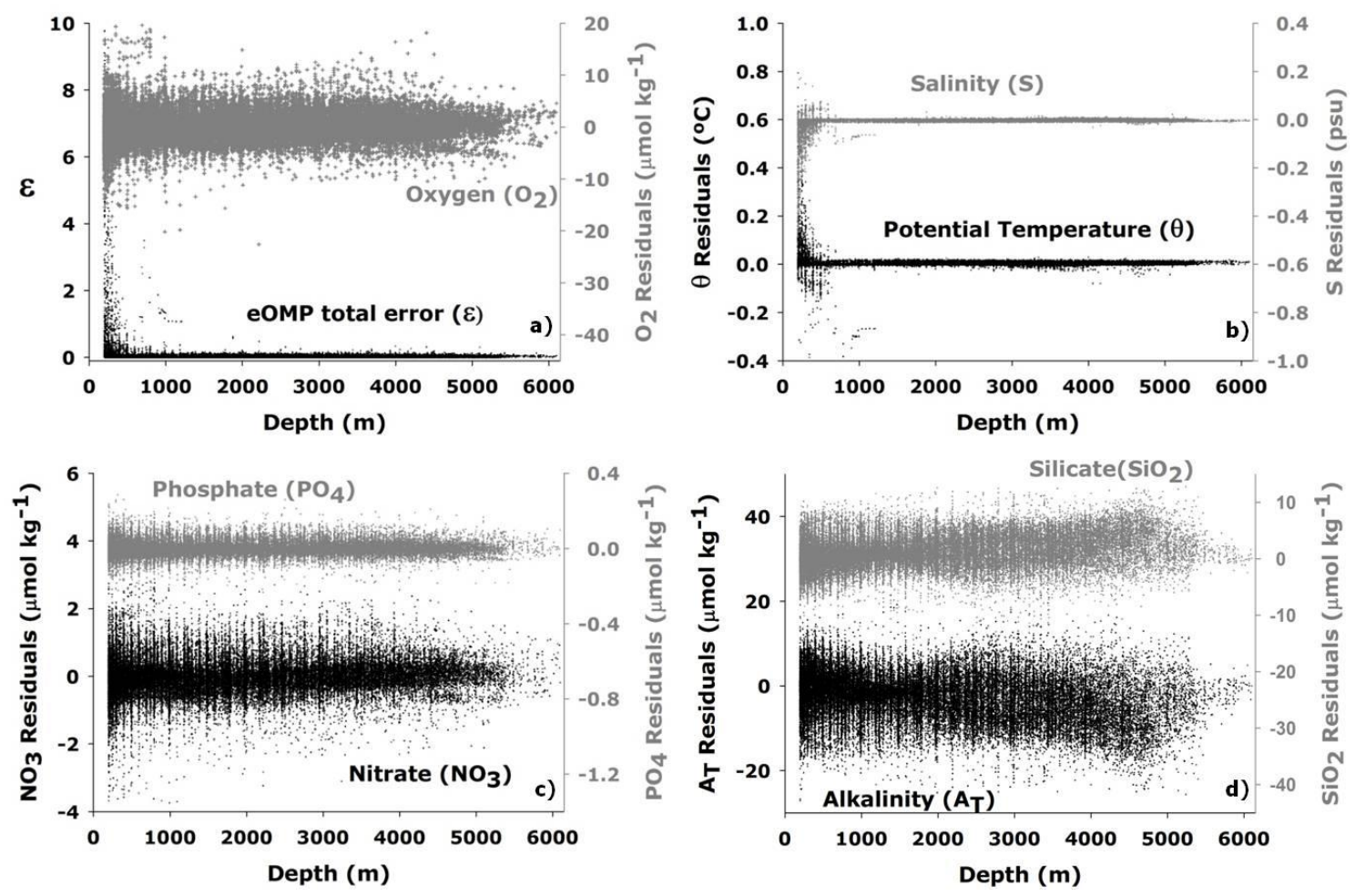

Figure 8. Values of the total error $(\varepsilon)$ of the extended OMP (eOMP) analysis (a)) and residuals (measured value - expected value of the property) of a) $\mathrm{O} 2$ (in $\mu$ molkg ${ }^{-1}$ ); b) $\theta$ and $\mathrm{S}$ (in ${ }^{\circ} \mathrm{C}$ and psu, respectively); c) NO3 and PO4 (both in $\mu$ molkg ${ }^{-1}$ ); d) AT and SiO2 (both in $\mu$ molkg ${ }^{-1}$ ). 

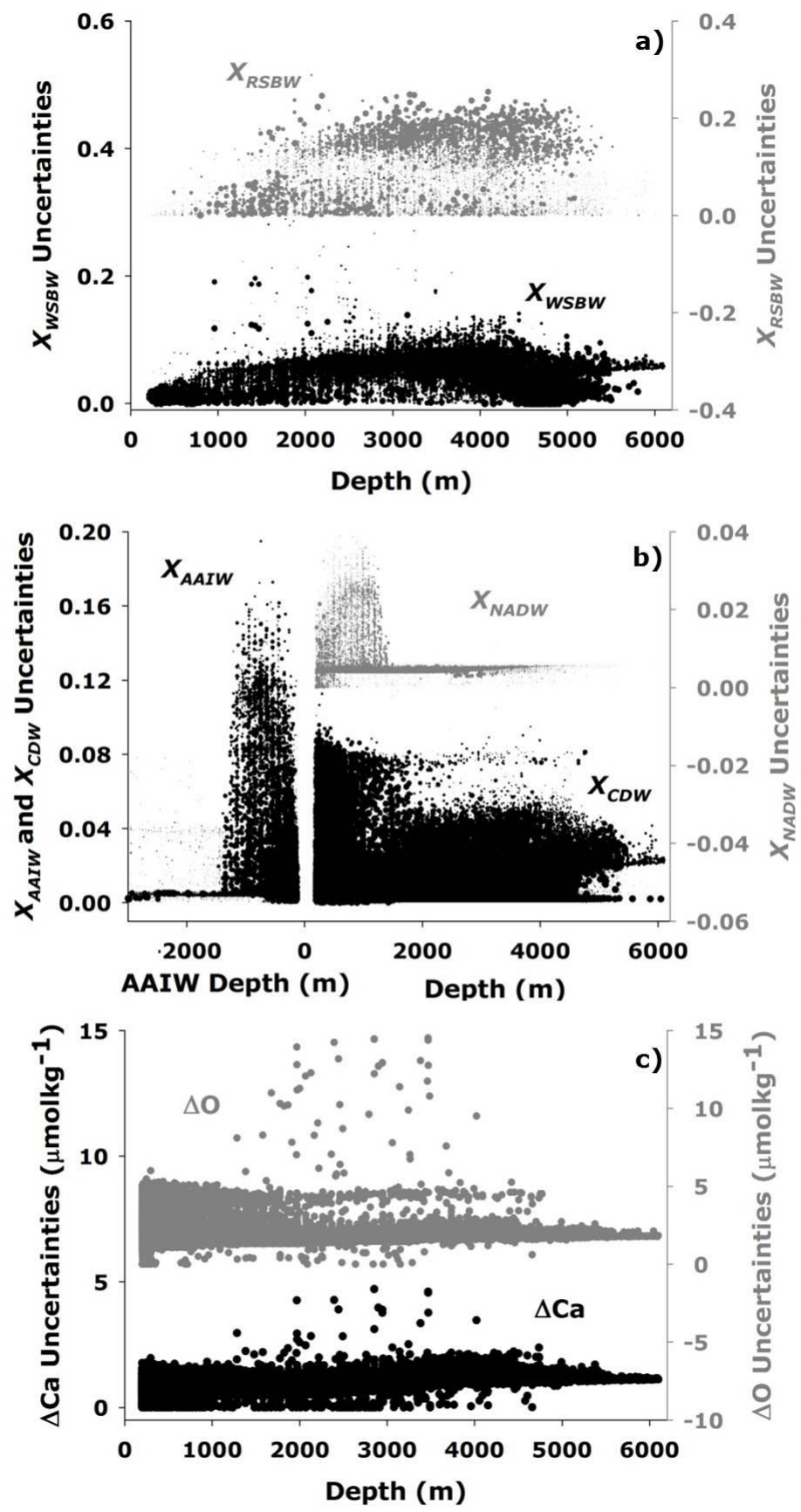

Figure 9. Distribution of the uncertainties of the contributions $\left(X_{i}\right)$ with depth for the main a) bottom waters $\left(X_{R S B W}\right.$ and $\left.\left.X_{W S B W}\right), \mathrm{b}\right)$ intermediate and deep waters $\left(X_{N A D W}, X_{A A I W}\right.$ and $\left.X_{C D W}\right)$, and c) for the terms $\Delta O$ and $\triangle C a$ (in $\mu \mathrm{molkg}^{-1}$ ). The size of the dots is proportional to the value of the contributions $\left(X_{i}\right)$ and the terms $(\triangle O, \triangle C a)$ themselves. 